\title{
Synthesis of ent-Thallusin
}

Xiaolei Gao, Barry B. Snider*

Department of Chemistry, MS 015, Brandeis University, Waltham, Massachusetts 02454-9110

and

Yoshihide Matsuo

Marine Biotechnology Institute Co. Ltd., 3-75-1 Heita, Kamaishi-shi, Iwate 026-0001, Japan

\section{Supporting Material}

Experimental Procedures

S2-S1 1

Copies of ${ }^{1} \mathrm{H}$ and ${ }^{13} \mathrm{C}$ NMR Spectra..

S12-S47 


\section{Experimental Section}

General Procedures. NMR spectra were recorded at $400 \mathrm{MHz}$ in $\mathrm{CDCl}_{3}$ unless otherwise indicated. Chemical shifts are reported in $\delta$, coupling constants in Hz, and IR spectra in $\mathrm{cm}^{-1}$. Oxidation of sclareol with $\mathrm{KMnO}_{4}$ and $\mathrm{MgSO}_{4}$ in acetone ${ }^{3}$ gave a hydroxy ketone, which was dehydrated to give sclareol oxide (6) by heating at reflux in benzene with a DeanStark trap. ${ }^{4}$

[4aR-(4a $\alpha, 6 \mathrm{a} \beta, 10 \mathrm{a} \alpha, 10 \mathrm{~b} \beta)]-2-B r o m o-3-(b r o m o m e t h y l)-4 a, 5,6,6 \mathrm{a}, 7,8,9,10,10 \mathrm{a}, 10 \mathrm{~b}-$ decahydro-4a,7,7,10a-tetramethyl-1H-naphtho[2,1-b]pyran (7). To a stirred solution of sclareol oxide (6) $(468 \mathrm{mg}, 1.79 \mathrm{mmol})$ in $\mathrm{CCl}_{4}(10 \mathrm{~mL})$ were added $\mathrm{CaCO}_{3}(393 \mathrm{mg}, 3.93$ mmol) and NBS (668 mg, $3.75 \mathrm{mmol})$. The reaction mixture was stirred at $25^{\circ} \mathrm{C}$ for $1 \mathrm{~h}$ and $\mathrm{H}_{2} \mathrm{O}(10 \mathrm{~mL})$ was added. The resulting mixture was extracted with ether $(150 \mathrm{~mL})$, which was washed with $\mathrm{H}_{2} \mathrm{O}$, dried $\left(\mathrm{MgSO}_{4}\right)$, and concentrated to give a colorless oil. Flash chromatography on silica gel (pentane) gave $456 \mathrm{mg}$ of $3(61 \%)$ as a colorless oil: $[\alpha]^{22}{ }_{\mathrm{D}}+117$ (c 1.21, $\left.\mathrm{CHCl}_{3}\right) ;{ }^{1} \mathrm{H}$ NMR 4.22 (d, 1, J=10.4), 3.88 (d, 1, $\left.J=10.4\right), 2.23-2.37$ (m, 2), 1.98 (ddd, $1, J=12.2,3.6,3.0), 1.70-1.75(\mathrm{~m}, 1), 1.63(\mathrm{dd}, 1, J=12.2,6.1), 1.51-1.61(\mathrm{~m}, 3), 1.35-1.49(\mathrm{~m}$, 2), 1.31 (dddd, $1, J=13.4,13.4,13.4,3.0), 1.19(\mathrm{~s}, 3), 1.14$ (ddd, $1, J=13.4,13.4,4.3), 0.91$ 0.97 (m, 2), 0.88 (s, 3), 0.82 (s, 3), 0.81 (s, 3); ${ }^{13} \mathrm{C}$ NMR 145.4, 99.4, 77.8, 55.8, 54.2, 41.7, 40.2, 39.1, 36.9, 33.4, 33.1, 30.6, 29.8, 21.5, 19.9, 19.6, 18.4, 14.9; IR 2927, 1127; HRMS (EI) calcd for $\mathrm{C}_{18} \mathrm{H}_{28} \mathrm{Br}_{2} \mathrm{O}\left(\mathrm{M}^{+}\right)$418.0507, found 418.0499.

A similar reaction with $190 \mathrm{mg}$ of sclareol oxide (6) in $\mathrm{CH}_{2} \mathrm{Cl}_{2}(5 \mathrm{~mL})$ instead of $\mathrm{CCl}_{4}$ gave 7 in $60 \%$ yield.

[4aR-(4a $\alpha, 6 a \beta, 10 \mathrm{a} \alpha, 10 \mathrm{~b} \beta)]-2-B r o m o-4 a, 5,6,6 \mathrm{a}, 7,8,9,10,10 \mathrm{a}, 10 \mathrm{~b}-d e c a h y d r o-$ 4a,7,7,10a-tetramethyl-1H-naphtho[2,1-b]pyran-3-methyl Acetate (8). To a stirred solution of 7 (456 mg, $1.09 \mathrm{mmol})$ in anhydrous DMF (10 mL) was added CsOAc (628 mg, $3.27 \mathrm{mmol})$ in one portion. The resulting mixture was stirred at $70^{\circ} \mathrm{C}$ for $4 \mathrm{~h}$, quenched with $\mathrm{H}_{2} \mathrm{O}(10 \mathrm{~mL})$, and extracted with ether $(3 \times 50 \mathrm{~mL})$. The combined organic layers were washed with $\mathrm{H}_{2} \mathrm{O}$, 
dried $\left(\mathrm{MgSO}_{4}\right)$, and concentrated to give a yellow oil, which was purified by flash chromatography on silica gel (50:1 hexanes/EtOAc) to give 8 (416 mg, 96\%) as a colorless oil: $[\alpha]^{22}{ }_{\mathrm{D}}+47\left(\mathrm{c} 2.07, \mathrm{CHCl}_{3}\right) ;{ }^{1} \mathrm{H}$ NMR $4.74(\mathrm{~d}, 1, J=12.2), 4.63(\mathrm{~d}, 1, J=12.2), 2.24-2.36(\mathrm{~m}, 2)$, $2.08(\mathrm{~s}, 3), 1.95(\mathrm{ddd}, 1, J=12.8,3.0,3.0), 1.68-1.75(\mathrm{~m}, 1), 1.64(\mathrm{dd}, 1, J=11.0,6.7), 1.52-$ $1.61(\mathrm{~m}, 3), 1.38-1.46(\mathrm{~m}, 2), 1.30$ (dddd, $1, J=13.4,13.4,13.4,3.0), 1.18(\mathrm{~s}, 3), 1.14$ (ddd, $1, J$ $=13.4,13.4,4.3), 0.93-0.97(\mathrm{~m}, 2), 0.88(\mathrm{~s}, 3), 0.82(\mathrm{~s}, 3), 0.81(\mathrm{~s}, 3) ;{ }^{13} \mathrm{C}$ NMR 170.6, 144.0, $99.5,77.6,63.4,55.7,53.8,41.6,40.1,39.0,36.8,33.3,33.1,29.7,21.4,20.8,20.2,19.5,18.3$, 14.8; IR 2938, 1744, 1667, 1448, 1379, 1229, 1025.

\section{$[4 a R-(4 a \alpha, 6 a \beta, 10 a \alpha, 10 b \beta)]-4 a, 5,6,6 a, 7,8,9,10,10 a, 10 b-D e c a h y d r o-4 a, 7,7,10 a-$} tetramethyl-1H-naphtho[2,1-b]pyran-3-carboxaldehyde (10). To a stirred solution of 8 (465 $\mathrm{mg}, 1.17 \mathrm{mmol})$ in $\mathrm{MeOH}(5 \mathrm{~mL})$ at $25{ }^{\circ} \mathrm{C}$ was added $\mathrm{K}_{2} \mathrm{CO}_{3}(807 \mathrm{mg}, 5.84 \mathrm{mmol})$. The resulting mixture was stirred at $25^{\circ} \mathrm{C}$ for $1 \mathrm{~h}$ and $\mathrm{H}_{2} \mathrm{O}(5 \mathrm{~mL})$ was added. The resulting mixture was extracted with ether $(3 \times 30 \mathrm{~mL})$. The combined organic layers were washed with $\mathrm{H}_{2} \mathrm{O}$, dried $\left(\mathrm{MgSO}_{4}\right)$, and concentrated to give crude $\mathbf{9}$ as a colorless oil that decomposed rapidly to give a dark green residue, which was purified by flash chromatography on silica gel (50:1 hexanes/EtOAc) to give 10 (298 mg, 92\%) as a colorless oil: $[\alpha]^{22}{ }_{\mathrm{D}}-68\left(\right.$ c $\left.1.45, \mathrm{CHCl}_{3}\right) ;{ }^{1} \mathrm{H}$ NMR $9.11(\mathrm{~s}, 1), 5.86(\mathrm{dd}, 1, J=5.0,2.5), 2.07-2.27(\mathrm{~m}, 3), 1.28-1.77(\mathrm{~m}, 8), 1.17(\mathrm{~s}, 3), 1.12-$ $1.20(\mathrm{~m}, 1), 0.93-1.01(\mathrm{~m}, 2), 0.90$ (s, 3), 0.85 (s, 3), 0.83 (s, 3); ${ }^{13} \mathrm{C}$ NMR 187.5, 151.0, 123.0, 78.0, 56.0, 51.9, 41.7, 40.5, 39.2, 36.8, 33.4, 33.1, 21.5, 19.8, 19.7, 19.6, 18.4, 15.0; IR 2925, 1692, 1637, 1388; HRMS (DCI/NH $\mathrm{NH}_{3}$ calcd for $\mathrm{C}_{18} \mathrm{H}_{32} \mathrm{NO}_{2}\left(\mathrm{MNH}_{4}{ }^{+}\right)$294.2433, found 294.2440.

Methyl [4aR-(4a $\alpha, 6 a \beta, 10 a \alpha, 10 b \beta)]-4 a, 5,6,6 a, 7,8,9,10,10 a, 10 b-D e c a h y d r o-4 a, 7,7,10 a-$ tetramethyl-1H-naphtho[2,1-b]pyran-3-carboxylate (2). To a stirred mixture of 10 (234 mg, $0.85 \mathrm{mmol})$ and 2,3-dimethyl-2-butene $(484 \mu \mathrm{L})$ in $t$ - $\mathrm{BuOH}(6 \mathrm{~mL})$ at $0{ }^{\circ} \mathrm{C}$ was added a solution of $80 \%$ of $\mathrm{NaClO}_{2}(106 \mathrm{mg})$ and $\mathrm{NaH}_{2} \mathrm{PO}_{4} \cdot \mathrm{H}_{2} \mathrm{O}(106 \mathrm{mg})$ in $\mathrm{H}_{2} \mathrm{O}(1 \mathrm{~mL})$. The resulting mixture was stirred at $25^{\circ} \mathrm{C}$ for $4 \mathrm{~h}$ and concentrated. The resulting residue was acidified by $2 \mathrm{M}$ aqueous $\mathrm{HCl}$ solution $(3 \mathrm{~mL})$ and extracted with EtOAc $(3 \times 30 \mathrm{~mL})$. A solution of diazomethane in ether was added to the combined EtOAc layers and $\mathrm{AcOH}$ was added to react 
with the excess diazomethane. Concentration of the resulting reaction mixture gave a yellow oil, which was purified by flash chromatography on silica gel (50:1 hexanes/EtOAc) to give 2 (208 mg, 80\%) as a white solid: $\operatorname{mp} 94{ }^{\circ} \mathrm{C} ;[\alpha]^{22}{ }_{\mathrm{D}}-4\left(\mathrm{c} 1.12, \mathrm{CHCl}_{3}\right) ;{ }^{1} \mathrm{H} \mathrm{NMR} 6.06(\mathrm{dd}, 1, J=5.5$, 2.4), 3.77 (s, 3), 1.92-2.12 (m, 3), 1.54-1.75 (m, 4), 1.38-1.49 (m, 3), 1.32 (dddd, 1, J = 13.4, $13.4,13.4,3.1), 1.17$ (s, 3), 1.15 (ddd, $1, J=13.4,13.4,4.3), 0.91-1.00(\mathrm{~m}, 2), 0.89$ (s, 3), 0.82 (s, 6); ${ }^{13} \mathrm{C}$ NMR 164.0, 141.8, 110.8, 77.9, 56.0, 52.0, 51.7, 41.7, 40.7, 39.2, 36.7, 33.4, 33.1, 21.5, 19.72, 19.69, 19.0, 18.4, 14.9; IR (KBr) 2924, 1734, 1252, 1107; HRMS (Q-Tof) calcd for $\mathrm{C}_{19} \mathrm{H}_{31} \mathrm{O}_{3}\left(\mathrm{MH}^{+}\right)$307.2273, found 307.2269.

Methyl 3-(2,6-Dicarbomethoxy-3-pyridinyl)-2-propenoate. A mixture of methyl 3bromo-2,6-pyridinedicarboxylate (3) (100 mg, $0.36 \mathrm{mmol})$, methyl acrylate $(115 \mu \mathrm{L}, 1.28$ $\mathrm{mmol}), \mathrm{Et}_{3} \mathrm{~N}(136 \mu \mathrm{L}, 0.98 \mathrm{mmol})$ and tri-o-tolylphophine $(18 \mathrm{mg}, 0.06 \mathrm{mmol})$ in $\mathrm{CH}_{3} \mathrm{CN}$ (1 $\mathrm{mL})$ was stirred at $25^{\circ} \mathrm{C}$ for $15 \mathrm{~min}$ and $\mathrm{Pd}(\mathrm{OAc})_{2}(9 \mathrm{mg}, 0.04 \mathrm{mmol})$ was added. The resulting mixture was stirred at $90{ }^{\circ} \mathrm{C}$ for $10 \mathrm{~h}$ and $\mathrm{H}_{2} \mathrm{O}(5 \mathrm{~mL})$ was added. The resulting reaction mixture was extracted with ether $(3 \times 30 \mathrm{~mL})$. The combined organic layers were washed with brine, dried $\left(\mathrm{MgSO}_{4}\right)$, and concentrated to give a yellow solid. Flash chromatography on silica gel (5:1 hexanes/EtOAc) gave the propenoate (97 mg, 95\%) as a white solid: $\mathrm{mp} 162{ }^{\circ} \mathrm{C} ;{ }^{1} \mathrm{H}$ NMR 8.32 $(\mathrm{d}, 1, J=16.0), 8.30(\mathrm{~d}, 1, J=8.0), 8.12(\mathrm{~d}, 1, J=8.0), 6.45(\mathrm{~d}, 1, J=16.0), 4.041(\mathrm{~s}, 3), 4.038$ (s, 3), 3.85 (s, 3); ${ }^{13} \mathrm{C}$ NMR 166.0, 165.2. 164.5, 147.9, 147.3, 139.6, 136.9, 134.7, 127.3, 124.2, 53.4, 53.3, 52.1; IR (KBr) 2958, 1732; HRMS (Q-Tof) calcd for $\mathrm{C}_{13} \mathrm{H}_{14} \mathrm{NO}_{6}\left(\mathrm{MH}^{+}\right)$280.0821, found 280.0808 .

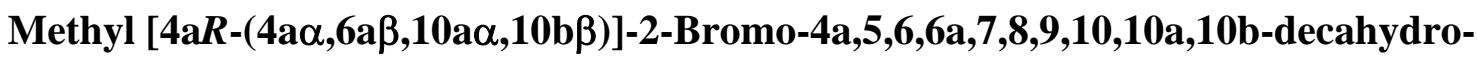
4a,7,7,10a-tetramethyl-1H-naphtho[2,1-b]pyran-3-carboxylate (4). Bromine $(12 \mu \mathrm{L}, 0.23$ mmol) was added dropwise to a stirred mixture of $2(62 \mathrm{mg}, 0.20 \mathrm{mmol})$ and $\mathrm{CaCO}_{3}(51 \mathrm{mg}$, $0.51 \mathrm{mmol})$ in $\mathrm{MeOH}(3 \mathrm{~mL})$ at $0{ }^{\circ} \mathrm{C}$. The resulting mixture was stirred at $0{ }^{\circ} \mathrm{C}$ for $30 \mathrm{~min}$ and $\mathrm{H}_{2} \mathrm{O}(5 \mathrm{~mL})$ was added to quench the reaction. The resulting mixture was extracted with ether (3 $\times 30 \mathrm{~mL})$. The combined organic layers were washed with $\mathrm{H}_{2} \mathrm{O}$ and brine, dried $\left(\mathrm{MgSO}_{4}\right)$, and concentrated to give a yellow oil, which was purified by flash chromatography on silica gel 
(100:1 hexanes/EtOAc) to give $4(37 \mathrm{mg}, 47 \%)$ as a colorless oil with spectral data identical to a sample obtained from oxidation of aldehyde 13.

Methyl [3S-(2 $\alpha, 3 \beta, 4 a \beta, 6 a \alpha, 10 a \beta, 10 b \alpha)-D o d e c a h y d r o-2-i o d o-3-m e t h o x y-4 a, 7,7,10 a-$ tetramethyl-1H-naphtho[2,1-b]pyran-3-carboxylate (11). ICl (3 $\mu \mathrm{L}, 0.060 \mathrm{mmol})$ was added to a stirred mixture of $2(16 \mathrm{mg}, 0.052 \mathrm{mmol})$ and $\mathrm{CaCO}_{3}(13 \mathrm{mg}, 0.13 \mathrm{mmol})$ in $\mathrm{MeOH}(1 \mathrm{~mL})$ at $0{ }^{\circ} \mathrm{C}$. The resulting mixture was stirred at $0{ }^{\circ} \mathrm{C}$ for 30 min and $\mathrm{H}_{2} \mathrm{O}(5 \mathrm{~mL})$ was added to quench the reaction. The resulting mixture was extracted with ether $(3 \times 30 \mathrm{~mL})$. The combined organic layers were washed with $\mathrm{H}_{2} \mathrm{O}$ and brine, dried $\left(\mathrm{MgSO}_{4}\right)$, and concentrated to give 11 (22 mg, 90\%) as an unstable white solid: ${ }^{1} \mathrm{H}$ NMR $4.70(\mathrm{dd}, 1, J=3.1,1.8), 3.78$ (s, 3), 3.25 (s, 3), 1.91-2.05 (m, 4), 1.15-1.77 (m, 8), $1.41(\mathrm{~s}, 3), 1.07$ (dd, 1, $J=12.8,2.4), 0.95$ (ddd, 1, $J=14.1$, $13.4,4.3), 0.88(\mathrm{~s}, 3), 0.82(\mathrm{~s}, 3), 0.80(\mathrm{~s}, 3)$.

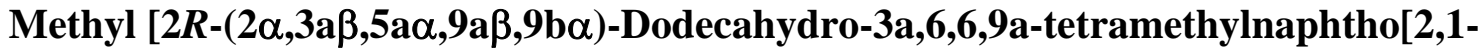

b]furan-2-oxoacetate (12). To a stirred solution of 2 (26 mg, $0.085 \mathrm{mmol})$ in $\mathrm{CH}_{3} \mathrm{CN}(1 \mathrm{~mL})$ was added $\mathrm{I}_{2}(26 \mathrm{mg}, 0.10 \mathrm{mmol})$ and CAN (51 mg, $\left.0.093 \mathrm{mmol}\right)$. The reaction mixture was stirred at $25^{\circ} \mathrm{C}$ for $1 \mathrm{~h}$ and quenched with saturated aqueous $\mathrm{Na}_{2} \mathrm{~S}_{2} \mathrm{O}_{3}$ solution $(5 \mathrm{~mL})$. The resulting mixture was extracted with $\mathrm{CH}_{2} \mathrm{Cl}_{2}(3 \times 20 \mathrm{~mL})$ and the combined organic layers were washed with brine, dried $\left(\mathrm{MgSO}_{4}\right)$, and concentrated. Flash chromatography on silica gel (10:1 hexanes/EtOAc) gave $12(26 \mathrm{mg}, 95 \%)$ as a white solid: $\mathrm{mp} 100{ }^{\circ} \mathrm{C} ;{ }^{1} \mathrm{H}$ NMR $4.99(\mathrm{dd}, 1, J=$ $10.4,3.0), 3.88(\mathrm{~s}, 3), 2.16(\mathrm{ddd}, 1, J=12.8,12.8,10.4), 1.94-2.02(\mathrm{~m}, 2), 1.78(\mathrm{br} \mathrm{d}, 1, J=$ 14.0), 1.58-1.70 (m, 1), $1.52(\mathrm{ddd}, 1, J=12.2,12.2,3.7), 1.37-1.44(\mathrm{~m}, 4), 1.30$ (ddd, $1, J=13.4$, 12.8, 3.0), 1.13-1.24 (m, 1), $1.19(\mathrm{~s}, 3), 0.89-1.04(\mathrm{~m}, 2), 0.87(\mathrm{~s}, 3), 0.84(\mathrm{~s}, 3), 0.82(\mathrm{~s}, 3) ;{ }^{13} \mathrm{C}$ NMR 194.3, 162.7, 83.4, 78.0, 58.4, 56.8, 52.7, 42.2, 39.7, 39.3, 36.3, 33.5, 33.0, 26.9, 21.6, 21.0, 20.6, 18.2, 15.0; IR (KBr) 2923, 1747, 1726; HRMS (EI) calcd for $\mathrm{C}_{19} \mathrm{H}_{30} \mathrm{O}_{3}\left(\mathrm{M}^{+}\right)$ 322.2144, found 322.2137. The stereochemistry of 12 was established by a 1D NOESY experiment. Irradiation of $\mathrm{H}_{2}$ at $\delta 4.99$ showed $\mathrm{NOEs}$ to $\mathrm{H}_{3 \mathrm{a}}$ at $\delta 1.19$ and $\mathrm{H}_{1 \beta}$ at $\delta 2.16$.

[4aR-(4a $\alpha, 6 \mathrm{a} \beta, 10 \mathrm{a} \alpha, 10 \mathrm{~b} \beta)]-2-B r o m o-4 a, 5,6,6 \mathrm{a}, 7,8,9,10,10 \mathrm{a}, 10 \mathrm{~b}-d e c a h y d r o-$ 4a,7,7,10a-tetramethyl-1H-naphtho[2,1-b]pyran-3-carboxaldehyde (13). To a stirred 
solution of 7 (404 mg, $0.97 \mathrm{mmol})$ in DMSO (10 mL) was added bis(2,4,6trimethylpyridine)silver(I) hexafluorophosphate $(675 \mathrm{mg}, 1.5 \mathrm{mmol})$ in one portion. A fine white precipitate was developed. The reaction mixture was stirred at $25^{\circ} \mathrm{C}$ for $5 \mathrm{~h}$ and $\mathrm{Et}_{3} \mathrm{~N}(2.5$ $\mathrm{mL}$ ) was added. (The yield is comparable if $\mathrm{Et}_{3} \mathrm{~N}$ is not added). The resulting mixture was stirred for another $15 \mathrm{~min}$ and extracted with ether $(3 \times 50 \mathrm{~mL})$, which was washed with $\mathrm{H}_{2} \mathrm{O}$ and brine, dried $\left(\mathrm{MgSO}_{4}\right)$, and concentrated to give a yellow oil. Chromatography on silica gel (100:1 hexanes/EtOAc) gave $13(298 \mathrm{mg}, 87 \%)$ as a white solid: $\mathrm{mp} 108^{\circ} \mathrm{C} ;[\alpha]^{22}{ }_{\mathrm{D}}-24(c) 3.92$, $\mathrm{CHCl}_{3}$ ); ${ }^{1} \mathrm{H}$ NMR 9.87 (s, 1), 2.47-2.59 (m, 2), 2.11 (ddd, 1, $\left.J=12.0,3.0,3.0\right), 1.73-1.79$ (m, 1), 1.55-1.70 (m, 4), 1.38-1.50 (m, 2), 1.29 (dddd, 1, $J=13.4,13.4,13.4,3.0), 1.19$ (s, 3), 1.16 (ddd, $1, J=14.3,13.4,4.2), 0.92-0.99(\mathrm{~m}, 2), 0.89(\mathrm{~s}, 3), 0.85(\mathrm{~s}, 3), 0.82(\mathrm{~s}, 3) ;{ }^{13} \mathrm{C} \mathrm{NMR} 186.3$, $144.5,117.7,78.3,55.6,53.5,41.5,39.9,39.0,36.9,33.3,33.0,31.8,21.4,20.0,19.5,18.3$, 14.7; IR (KBr) 2945, 1689.

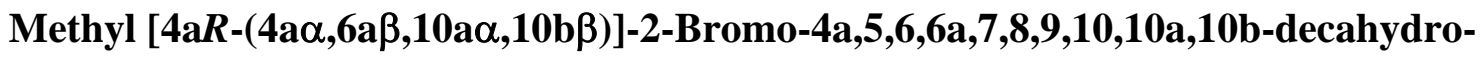
4a,7,7,10a-tetramethyl-1H-naphtho[2,1-b]pyran-3-carboxylate (4). To a stirred solution of acetic acid $(125 \mu \mathrm{L}, 2.10 \mathrm{mmol})$ in $\mathrm{MeOH}(5 \mathrm{~mL})$ were added $\mathrm{NaCN}$ (206mg, $4.21 \mathrm{mmol})$, a solution of $13(298 \mathrm{mg}, 0.84 \mathrm{mmol})$ in $\mathrm{MeOH}(3 \mathrm{~mL})$ and precipitated active $\mathrm{MnO}_{2}(1.464 \mathrm{~g}$, $16.64 \mathrm{mmol})$. The reaction mixture was stirred at $25^{\circ} \mathrm{C}$ under $\mathrm{N}_{2}$ for $12 \mathrm{~h}$ and filtered. $\mathrm{H}_{2} \mathrm{O}(5$ $\mathrm{mL})$ was added to the filtrate, which was extracted with ether $(3 \times 30 \mathrm{~mL})$. The combined ether layers were washed with brine, dried $\left(\mathrm{MgSO}_{4}\right)$, and concentrated to give a yellow oil.

Chromatography on silica gel (100:1 hexanes/EtOAc) gave 4 (320 mg, 99\%) as a colorless oil: $[\alpha]^{22}{ }_{\mathrm{D}}+37\left(\right.$ c 6.20, $\left.\mathrm{CHCl}_{3}\right) ;{ }^{1} \mathrm{H}$ NMR 3.80 (s, 3), 2.33-2.48 (m, 2), 2.04 (ddd, 1, $J=12.0,3.0$, 3.0), 1.71-1.77 (m, 1), $1.65(\mathrm{dd}, 1, J=12.2,6.1), 1.54-1.63(\mathrm{~m}, 3), 1.38-1.48(\mathrm{~m}, 2), 1.31$ (dddd, $1, J=13.4,13.4,13.4,3.1), 1.22$ (s, 3), $1.15(\mathrm{ddd}, 1, J=12.8,12.8,4.9), 0.91-0.97$ (m, 2), 0.89 (s, 3), 0.828 (s, 3), 0.815 (s, 3); ${ }^{13} \mathrm{C}$ NMR 163.0, 139.9, 103.8, 78.2, 55.6, 53.4, 52.2, 41.5, 39.9, 38.9, 36.7, 33.3, 33.0, 31.1, 21.4, 19.9, 19.5, 18.2, 14.6; IR 2927, 1738; HRMS (Q-Tof) calcd for $\mathrm{C}_{19} \mathrm{H}_{30} \mathrm{O}_{3} \mathrm{Br}\left(\mathrm{MH}^{+}\right)$385.1378, found 385.1370. 
Methyl 3-Tributylstannyl-2,6-pyridinedicarboxylate (5). A mixture of methyl 3bromo-2,6-pyridinedicarboxylate $(3)^{2}(1.01 \mathrm{~g}, 3.69 \mathrm{mmol}),\left(\mathrm{Ph}_{3} \mathrm{P}\right)_{2} \mathrm{PdCl}_{2}(51 \mathrm{mg}, 0.074 \mathrm{mmol})$ and bis(tributyltin) $(5.6 \mathrm{~mL}, 11.06 \mathrm{mmol})$ in toluene $(25 \mathrm{~mL})$ was stirred at reflux for $3 \mathrm{~h}$ and concentrated. Flash chromatography on silica gel (20:1 hexanes/EtOAc) gave 5 (728 mg, 41\%) as a colorless oil: ${ }^{1} \mathrm{H}$ NMR $8.19(\mathrm{~s}, 2), 4.03(\mathrm{~s}, 3), 4.02(\mathrm{~s}, 3), 1.46$ (tt, 6, J=7.3, 7.3), 1.29 (tq, $6, J=7.3,7.3), 1.12(\mathrm{t}, 6, J=7.3), 0.85(\mathrm{t}, 9, J=7.3) ;{ }^{13} \mathrm{C} \mathrm{NMR} 167.5,165.7,152.3,147.6$, 147.4, 147.2, 126.5, 53.4, 53.1, 29.0 (3 C), 27.3 (3 C), 13.6 (3 C), 11.3 (3 C); IR 2955, 2922, 1713, 1443, 1322, 1140; HRMS (EI) calcd for $\mathrm{C}_{21} \mathrm{H}_{34} \mathrm{NO}_{4}{ }^{116} \mathrm{Sn}\left(\mathrm{M}-\mathrm{H}^{+}\right) 480.1505$, found 480.1506. Minor satellite peaks are present in the ${ }^{1} \mathrm{H}$ NMR spectrum at $\delta 0.90-1.57$, and 8.148.25, and in the ${ }^{13} \mathrm{C}$ NMR spectrum at $\delta 27.3$ and 11.3 due to the coupling of adjacent protons and carbons to ${ }^{117} \mathrm{Sn}$ and ${ }^{119} \mathrm{Sn}$.

Tetramethyl 3,3'-Bipyridine-2,2',6,6'-tetracarboxylate. A mixture of bromo ester 4 (7.3 mg, $0.019 \mathrm{mmol})$, stannylpyridine 5 (19 mg, $0.039 \mathrm{mmol}),\left(\mathrm{Ph}_{3} \mathrm{P}\right)_{4} \mathrm{Pd}(3 \mathrm{mg}, 0.002 \mathrm{mmol})$ and $\mathrm{CuI}(4 \mathrm{mg}, 0.021 \mathrm{mmol})$ in DMF $(1 \mathrm{~mL})$ was degassed three times by the freeze-and-thaw method and stirred at $50{ }^{\circ} \mathrm{C}$ for $12 \mathrm{~h}$. The resulting reaction mixture was filtered through Celite and the filtrate was concentrated to give a brown residue. Flash chromatography on silica gel (100:1 to 1:1 hexanes/EtOAc) gave recovered 4 (6 mg, 86\%) and $13(1.0 \mathrm{mg}, 10 \%)$, followed by $12 \mathrm{mg}(80 \%)$ of the biyprydine as a colorless oil: ${ }^{1} \mathrm{H}$ NMR $8.38(\mathrm{~d}, 2, J=8.0), 7.81(\mathrm{~d}, 2, J=$ 8.0), 4.07 (s, 6), 3.79 (s, 6); ${ }^{13} \mathrm{C}$ NMR 164.8 (2 C), 164.7 (2 C), 147.4 (2 C), 146.2 (2 C), 139.2 (2 C), 138.9 (2 C), 126.9 (2 C), 53.4 (2 C), 53.1 (2 C); IR 1728, 1441, 1323; HRMS (Q-Tof) calcd for $\mathrm{C}_{18} \mathrm{H}_{17} \mathrm{~N}_{2} \mathrm{O}_{8}\left(\mathrm{MH}^{+}\right)$389.0985, found 389.0977.

\section{Dimethyl 3-[(4aR,6aS,10aS,10bR)-4a,5,6,6a,7,8,9,10,10a,10b-Decahydro-3-} (methoxycarbonyl)-4a,7,7,10a-tetramethyl-1H-naphtho[2,1-b]pyran-2-yl]-2,6pyridinedicarboxylate (Me1, 14). A mixture of $4(65 \mathrm{mg}, 0.17 \mathrm{mmol})$ and $\left(\mathrm{Ph}_{3} \mathrm{P}\right){ }_{4} \mathrm{Pd}(260 \mathrm{mg}$, $0.17 \mathrm{mmol}$ ) in DMF (15 mL containing $15 \mu \mathrm{L}$ of $\mathrm{H}_{2} \mathrm{O}$ ) was degassed three times by the freezeand-thaw method and stirred at $60{ }^{\circ} \mathrm{C}$ for $6 \mathrm{~h}$. A suspension of $5(121 \mathrm{mg}, 0.25 \mathrm{mmol})$ and $\mathrm{CuI}$ (47 mg, $0.25 \mathrm{mmol})$ in DMF (15 mL containing $15 \mu \mathrm{L}$ of $\mathrm{H}_{2} \mathrm{O}$ ) was added. The resulting 
reaction mixture was stirred at $60{ }^{\circ} \mathrm{C}$ for $12 \mathrm{~h}$ and filtered through Celite. The filtrate was concentrated to give a brown residue. Flash chromatography on silica gel (5:1 hexanes/EtOAc) gave $14(45 \mathrm{mg}, 54 \%)$ as a pale yellow oil: $[\alpha]^{22}{ }_{\mathrm{D}}+42\left(\right.$ c $\left.0.78, \mathrm{CHCl}_{3}\right) ;{ }^{1} \mathrm{H} \mathrm{NMR}\left(20{ }^{\circ} \mathrm{C}\right) 8.23$ $(\mathrm{d}, 1, J=8.0), 7.68(\mathrm{~d}, 1, J=8.0), 4.02(\mathrm{~s}, 3), 3.91(\mathrm{~s}, 3), 3.50(\mathrm{~s}, 3), 2.18-2.28(\mathrm{~m}, 2), 2.14(\mathrm{br} \mathrm{d}$, $1, J=12.2), 1.33-1.80(\mathrm{~m}, 8), 1.36(\mathrm{~s}, 3), 1.17(\mathrm{ddd}, 1, J=13.5,12.8,3.7), 1.05$ (br d, $1, J=$ 12.2), 1.00 (br dd, 1, $J=14.0,14.0), 0.91(\mathrm{~s}, 3), 0.85(\mathrm{~s}, 3), 0.83(\mathrm{~s}, 3) ;\left(55^{\circ} \mathrm{C}\right) 8.18(\mathrm{~d}, 1, J=$ 8.0), $7.64(\mathrm{~d}, 1, J=8.0), 4.00(\mathrm{~s}, 3), 3.90(\mathrm{~s}, 3), 3.48(\mathrm{~s}, 3), 2.19-2.33(\mathrm{~m}, 2), 2.13(\mathrm{ddd}, 1, J=$ 12.2, 3.0, 3.0), 1.55-1.80 (m, 5), 1.33-1.46 (m, 3), 1.36 (s, 3), $1.18(\mathrm{ddd}, 1, J=13.4,13.4,4.0)$, 1.06 (br d, 1, $J=12.2), 1.00(\mathrm{ddd}, 1, J=14.0,12.2,3.7), 0.91$ (s, 3), $0.86(\mathrm{~s}, 3), 0.84$ (s, 3); $\left(30{ }^{\circ} \mathrm{C}, 500 \mathrm{MHz}\right) 8.22(\mathrm{~d}, 1, J=8.0), 7.67(\mathrm{~d}, 1, J=8.0), 4.02(\mathrm{~s}, 3), 3.91(\mathrm{~s}, 3), 3.50(\mathrm{~s}, 3)$, 2.18-2.28 (m, 2), 2.14 (br dd, $1, J=12.2,3.0), 1.33-1.80(\mathrm{~m}, 8), 1.37$ (s, 3), 1.18 (br dd, $1, J=$ 13.5, 12.8), 1.06 (br d, 1, $J=12.2), 1.00$ (br dd, $1, J=14.0,14.0), 0.92(\mathrm{~s}, 3), 0.86(\mathrm{~s}, 3), 0.84$ (s, 3); (DMSO-d $\left.30{ }^{\circ} \mathrm{C}, 500 \mathrm{MHz}\right) 8.16(\mathrm{~d}, 1, J=8.0), 7.97(\mathrm{~d}, 1, J=8.0), 3.91(\mathrm{~s}, 3), 3.79(\mathrm{~s}, 3)$, $3.41(\mathrm{~s}, 3), 2.21-2.23(\mathrm{~m}, 2), 2.00$ (br d, 1, J=12.2), 1.69 (br d, 1, J=12.7), 1.51-1.62 (m, 4), 1.35-1.41 (m, 3), 1.26 (s, 3), 1.15 ( br dd, 1, J=13.2, 12.7), 1.02 (br d, 1, J=12.2), 0.96 (br dd, $1, J=12.7,12.7), 0.89(\mathrm{~s}, 3), 0.81(\mathrm{~s}, 6) ;{ }^{13} \mathrm{C} \mathrm{NMR}\left(20{ }^{\circ} \mathrm{C}\right) 165.6$ (br), 165.0, 163.2, 147.7 (br), 145.7, 141.3 (br), 138.9 (2 C), 126.6, 119.6 (br), 78.2, 55.9, 53.1, 52.9, 52.0, 51.6, 41.6, 40.4, $39.1,36.7,33.4,33.1,27.4,21.5,20.4,19.7,18.4,14.9 ;\left(55^{\circ} \mathrm{C}\right) 165.8,165.1,163.3,148.2$, 146.0, 141.0, 138.8, 138.7, 126.4, 119.1, 78.2, 56.2, 52.9, 52.7, 52.0, 51.7, 41.9, 40.7, 39.4, 36.9, 33.4, 33.2, 27.5, 21.5, 20.5, 19.8, 18.5, 14.9; IR 2951, 1731; HRMS (Q-Tof) calcd for $\mathrm{C}_{28} \mathrm{H}_{38} \mathrm{NO}_{7}\left(\mathrm{MH}^{+}\right)$500.2648, found 500.2642. The $500 \mathrm{MHz}{ }^{1} \mathrm{H}$ NMR spectra of Me1 (14) in both $\mathrm{CDCl}_{3}$ and DMSO- $d_{6}$ are identical to those of natural Me1. The reported ${ }^{13} \mathrm{C}$ NMR spectral data for natural Me1 were obtained from HSQC and HMBC spectral correlations and differ from our direct ${ }^{13} \mathrm{C}$ NMR spectral data of Me1 by $\delta$ 0.2-1.6 for most carbons.

14 can also be prepared by the following procedure. A mixture of 4 ( $4.4 \mathrm{mg}, 0.011 \mathrm{~mol})$ and $\left(\mathrm{Ph}_{3} \mathrm{P}\right)_{4} \mathrm{Pd}(18 \mathrm{mg}, 0.011 \mathrm{mmol})$ in DMF $\left(1 \mathrm{~mL}\right.$ containing $1 \mu \mathrm{L}$ of $\left.\mathrm{H}_{2} \mathrm{O}\right)$ in a CEM $10 \mathrm{~mL}$ tube containing a stirring bar was degassed three times by the freeze-and-thaw method and 
heated in a microwave oven $\left(73 \mathrm{w}, 6 \mathrm{psi}, 90^{\circ} \mathrm{C}\right)$ for $15 \mathrm{~min}$. A suspension of $5(8.2 \mathrm{mg}, 0.017$ mmol) and $\mathrm{CuI}(3.3 \mathrm{mg}, 0.017 \mathrm{mmol})$ in $\mathrm{DMF}\left(1 \mathrm{~mL}\right.$ containing $1 \mu \mathrm{L}$ of $\left.\mathrm{H}_{2} \mathrm{O}\right)$ was added and the resulting mixture was heated in the microwave oven $\left(62 \mathrm{w}, 5 \mathrm{psi}, 90^{\circ} \mathrm{C}\right)$ for another $30 \mathrm{~min}$. The reaction mixture was filtered through Celite, which was washed with $\mathrm{CH}_{2} \mathrm{Cl}_{2}$. The combined filtrate was concentrated to give a brown residue. Flash chromatography on silica gel (5:1 hexanes/EtOAc) gave $5.2 \mathrm{mg}(92 \%)$ of $\mathbf{1 4}$ as a pale yellow oil. A similar reaction at a 5 times larger scale gave only less than $20 \%$ of 14 , presumably due to less efficient stirring.

Trisodium Salt of (3-[(4aR,6aS,10aS,10bR)-3-Carboxy-4a,5,6,6a,7,8,9,10,10a,10bdecahydro-4a,7,7,10a-tetramethyl-1H-naphtho[2,1-b]pyran-2-yl]-2,6-pyridinedicarboxylic acid) (ent-Thallusin, 1). $40 \%$ Aqueous $\mathrm{NaOD}$ solution $(15 \mu \mathrm{L}, 0.15 \mathrm{mmol})$ was added to a mixture of $14(14.5 \mathrm{mg}, 0.029 \mathrm{mmol})$ in $\mathrm{D}_{2} \mathrm{O}(1 \mathrm{~mL})$. The reaction mixture was stirred at $100{ }^{\circ} \mathrm{C}$ for $30 \mathrm{~min}$ and cooled at $25^{\circ} \mathrm{C}$. The ${ }^{1} \mathrm{H}$ NMR spectrum indicated the complete hydrolysis of the methyl ester. Removal of the solvent gave a mixture of trisodium salt $\mathbf{1}$ and NaOD as a white solid (20 mg): ${ }^{1} \mathrm{H}$ NMR ( $\left.\mathrm{D}_{2} \mathrm{O}\right) 7.72$ (d, 1, $\left.J=7.9\right), 7.59$ (d, 1, J= 7.9), 2.24 (dd, 1, $J=17.1$, 12.8), 2.10 (dd, $1, J=17.1,4.9), 1.96$ (br d, $1, J=12.2), 1.69$ (br d, $1, J=13.4), 1.45-1.57$ (m, 4), $1.28-1.38(\mathrm{~m}, 3), 1.23$ (s, 3), 1.08 (br dd, 1, J=13.4, 13.4), 0.98 (br d, 1, $J=11.6$ ), 0.88 (br $\mathrm{dd}, 1, J=14.0,12.2), 0.81$ (s, 3), 0.77 (s, 3), 0.75 (s, 3); ${ }^{13} \mathrm{C}$ NMR 176.0, 173.8, 172.2, 154.8. $150.9,144.5,140.0,136.5,123.6,113.6,79.0,56.1,52.5,42.0,40.9,39.3,37.0,33.4,33.1,25.5$, 21.6, 20.6, 20.0, 18.8, 15.0; IR (KBr) 3466, 1618, 1389, 1104; HRMS (Q-Tof) calcd for $\mathrm{C}_{25} \mathrm{H}_{29} \mathrm{NO}_{7} \mathrm{Na}_{3}\left(\mathrm{MH}^{+}\right)$524.1637, found 524.1621. The ${ }^{1} \mathrm{H} \mathrm{NMR}$ and ${ }^{13} \mathrm{C}$ NMR spectral data of 1 are similar to but don't exactly match those reported for thallusin because the spectra are sensitive to both $\mathrm{pH}$ and concentration. The ${ }^{1} \mathrm{H}$ NMR spectral data of $\mathbf{1}$ are shifted upfield by 0.05-0.11 ppm compared to those of the natural product. The ${ }^{13} \mathrm{C}$ NMR spectral data of $\mathbf{1 1}$ are within $1.1 \mathrm{ppm}$ of those reported for thallusin except for two carbons $\left(176.3, \operatorname{lit}^{1} 174.7 ; 155.2\right.$, $\left.\operatorname{lit}^{1} 152.7\right)$.

3-[(4aR,6aS,10a $S, 10 \mathrm{~b} R)-4 \mathrm{a}, 5,6,6 \mathrm{a}, 7,8,9,10,10 \mathrm{a}, 10 \mathrm{~b}-D e c a h y d r o-3-(h y d r o x y m e t h y l)-$ 4a,7,7,10a-tetramethyl-1H-naphtho[2,1-b]pyran-2-yl]-2,6-pyridinedimethanol (Me1H1, 15). 
To a stirred solution of 14 (42 $\mathrm{mg}, 0.084 \mathrm{mmol})$ in diethyl ether $(20 \mathrm{~mL})$ and $\mathrm{MeOH}(5 \mathrm{~mL})$ was added $\mathrm{NaBH}_{4}(93 \mathrm{mg}, 2.45 \mathrm{mmol})$ at $25^{\circ} \mathrm{C}$. The reaction mixture was stirred for $1 \mathrm{~h}$ and quenched with saturated aqueous $\mathrm{NH}_{4} \mathrm{Cl}$ solution $(2 \mathrm{~mL})$. The resulting mixture was stirred for $10 \mathrm{~min}$ and concentrated to dryness to remove the solvent. $1 \mathrm{~mL}$ of $\mathrm{MeOH}$ was added followed by $10 \mathrm{~mL}$ of $\mathrm{CH}_{2} \mathrm{Cl}_{2}$. The white precipitate was filtered and washed with $\mathrm{CH}_{2} \mathrm{Cl}_{2}$. The combined filtrate was concentrated to give $58 \mathrm{mg}$ of crude triol 15. Chromatography on silica gel (20:1 $\left.\mathrm{CH}_{2} \mathrm{Cl}_{2} / \mathrm{MeOH}\right)$ gave $32 \mathrm{mg}(91 \%)$ of 15 as a colorless oil: $[\alpha]^{22}+77$ (c $\left.0.41, \mathrm{CHCl}_{3}\right)$; $\left\{\right.$ lit. $\left.^{1}[\alpha]^{22}{ }_{\mathrm{D}}-73.5\left(c \mathrm{0.39}, \mathrm{CHCl}_{3}\right)\right\} ;{ }^{1} \mathrm{H}$ NMR $7.42(\mathrm{~d}, 1, J=7.9), 7.12(\mathrm{~d}, 1, J=7.9), 4.74-4.91$ $(\mathrm{m}, 1), 4.78($ br s, 2), $4.65(\mathrm{~d}, 1, J=14.0)$ (major rotamer), $4.57(\mathrm{~d}, 1, J=14.6)$ (minor rotamer) 3.60-3.73 (m, 2), 1.93-2.02 (m, 3), 1.74 (br d, 1, J=12.8), 1.60-1.64 (m, 2), 1.52-1.55 (m, 2), $1.32-1.41(\mathrm{~m}, 3), 1.26(\mathrm{~s}, 3), 1.15(\mathrm{ddd}, 1, J=12.8,12.8,3.0), 1.01$ (br d, 1, J=12.2), 0.94 (br $\mathrm{dd}, 1, J=12.8,12.8), 0.90(\mathrm{~s}, 3), 0.81(\mathrm{~s}, 6)$; (low concentration) 7.47 (d, 1, J=8.0), 7.22 (d, 1, $J$ $=8.0), 4.79$ (br s, 2), $4.78(\mathrm{~d}, 1, J=14.4), 4.64$ (d, 1, J =14.4), 3.73 (d, 1, J = 12.2), $3.64(\mathrm{~d}, 1, J$ $=12.2), 1.96-2.08(\mathrm{~m}, 3), 1.77(\mathrm{br} \mathrm{d}, 1, J=13.4), 1.52-1.68(\mathrm{~m}, 4), 1.34-1.44(\mathrm{~m}, 3), 1.32(\mathrm{~s}, 3)$, 1.16 (br dd, $1, J=12.2,11.0), 0.95-1.04(\mathrm{~m}, 2), 0.91(\mathrm{~s}, 3), 0.83(\mathrm{~s}, 6) ;{ }^{13} \mathrm{C}$ NMR (minor rotamer in parentheses)156.9, 156.3, 147.7 (147.5), 139.2 (138.9), 132.6 (132.3), 119.1, 105.8 (105.9), 76.8 (76.9), 64.2, 62.6 (62.2), 60.0 (60.3), 56.1 (55.9), 52.5, 41.8, 40.6, 39.2, 36.7, 33.4, 33.1, 25.1 (24.8), 21.5, 20.7 (20.4), 19.7, 18.4, 14.9; IR 3333, 2925, 1459, 1020; HRMS (Q-Tof) calcd for $\mathrm{C}_{25} \mathrm{H}_{38} \mathrm{NO}_{4}\left(\mathrm{MH}^{+}\right)$416.2801, found 416.2801. The ${ }^{1} \mathrm{H}$ NMR spectral data of 15 are similar to, but don't exactly match those reported for Me1H1 because the spectra are sensitive to both $\mathrm{pH}$ and concentration. The ${ }^{13} \mathrm{C}$ NMR spectra data of 15 are within $0.2 \mathrm{ppm}$ of those reported for Me1H1 except for two carbons $\left\{139.2\right.$ (138.9), $\operatorname{lit}^{1} 139.7$ (138.8); 64.2, $\left.\operatorname{lit}^{1} 64.5\right\}$.

Me1H1W4 (16). To a stirred solution of 15 (15 mg, $0.036 \mathrm{mmol})$ in $\mathrm{MeOH}(5 \mathrm{~mL})$ was added $6 \mathrm{M}$ aqueous $\mathrm{HCl}$ solution $(1 \mathrm{~mL})$. The reaction mixture was stirred at $25^{\circ} \mathrm{C}$ for $1 \mathrm{~h}$ and evaporated to dryness. The residue was purified by chromatography on silica gel (20:1

$\left.\mathrm{CH}_{2} \mathrm{Cl}_{2} / \mathrm{MeOH}\right)$ gave $13 \mathrm{mg}(87 \%)$ of a $6: 1$ mixture with 16 as the major product.

Recrystallization from ether gave $8 \mathrm{mg}(53 \%)$ of $\mathbf{1 6}$ as a white solid: $\mathrm{mp} 211^{\circ} \mathrm{C}$; \{lit. ${ }^{1} \mathrm{mp} 215.5$ - 
$\left.216.5^{\circ} \mathrm{C}\right\}[\alpha]^{22}{ }_{\mathrm{D}}+36(c 0.08, \mathrm{MeOH}) ;\left\{\right.$ lit. $\left.^{1}[\alpha]^{22}{ }_{\mathrm{D}}-41(c 0.10, \mathrm{MeOH})\right\} ;{ }^{1} \mathrm{H}$ NMR $7.47(\mathrm{~d}, 1, J=$ 8.0), $7.10(\mathrm{~d}, 1, J=8.0), 4.99(\mathrm{~d}, 1, J=17.2), 4.83(\mathrm{~d}, 1, J=17.2), 4.72(\mathrm{br} \mathrm{d}, 2, J=4.2), 3.56$ (t, 1, OH, $J=4.2), 3.52(\mathrm{dd}, 1, J=11.0,4.0), 3.41(\mathrm{dd}, 1, J=11.0,9.1), 2.94(\mathrm{dd}, 1, J=12.2,5.5)$, $2.10(\mathrm{dd}, \mathrm{OH}, 1, J=9.1,4.0), 1.91$ (br d, $1, J=12.2), 1.81$ (br dd, $1, J=14.2,4.4), 1.60-1.74$ (m, 4), 1.25-1.49 (m, 5), 1.43 (s, 3), 1.17 (ddd, 1, J=14.1, 12.8, 4.2), 0.99 (br d, 1, J=12.0), 0.95 (ddd, $1, J=12.8,12.8,3.7), 0.89$ (s, 3), $0.81(\mathrm{~s}, 3), 0.77$ (s, 3); ${ }^{13} \mathrm{C}$ NMR 157.0, 151.3, 137.5, $131.2,118.9,98.0,77.1,66.4,64.8,63.8,57.4,56.4,42.2,42.0,39.2,38.8,36.9,33.3$ (2 C), 25.6, 23.9, 21.2, 19.6, 18.5, 15.8; IR 3426, 2927, 2865, 1466, 1082; HRMS (Q-Tof) calcd for $\mathrm{C}_{25} \mathrm{H}_{38} \mathrm{NO}_{4}\left(\mathrm{MH}^{+}\right)$416.2801, found 416.2799. The ${ }^{1} \mathrm{H}$ NMR spectral data of $\mathbf{1 6}$ are similar to, but don't exactly match those reported for Me1H1W4 because the spectra are sensitive to both $\mathrm{pH}$ and concentration. The ${ }^{13} \mathrm{C}$ NMR spectral data of $\mathbf{1 6}$ are within $0.1 \mathrm{ppm}$ of those reported for Me1H1W4 except for one carbon $\left(77.4, \operatorname{lit}^{1} 77.1\right)$. The minor product from the cyclization of 15 to give $\mathbf{1 6}$ was not characterized, but is probably one of the three possible stereoisomers of $\mathbf{1 6 .}$ 


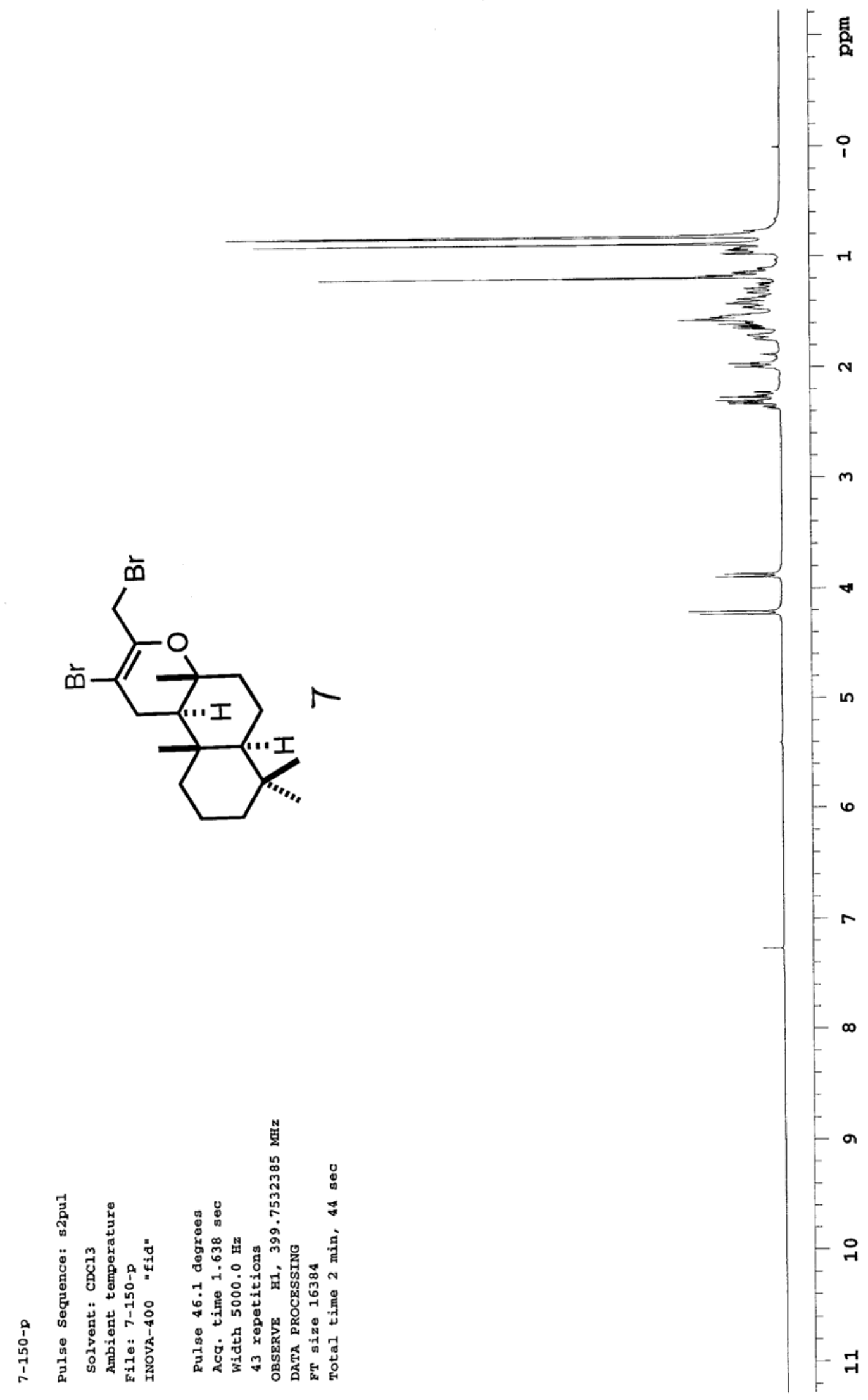



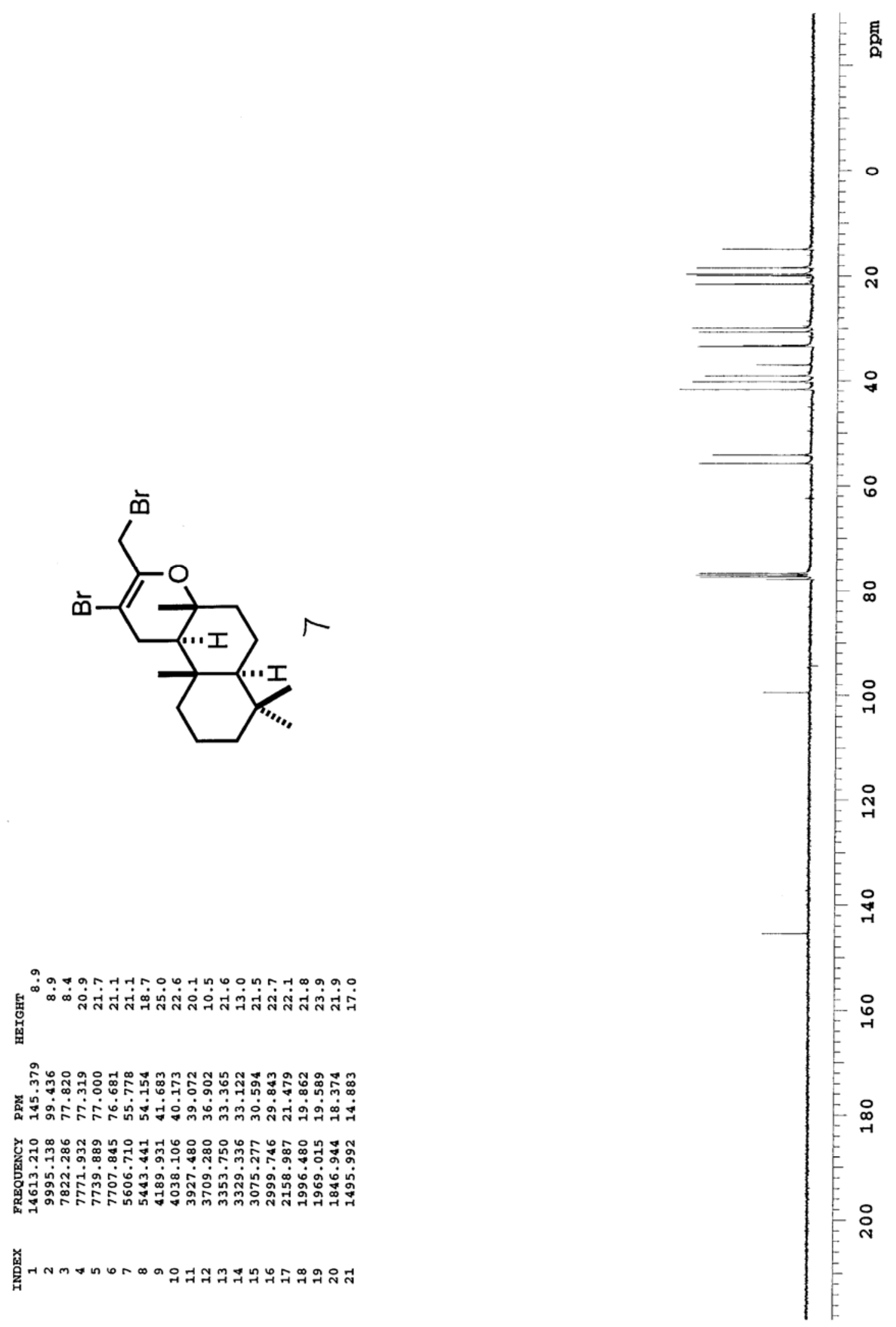


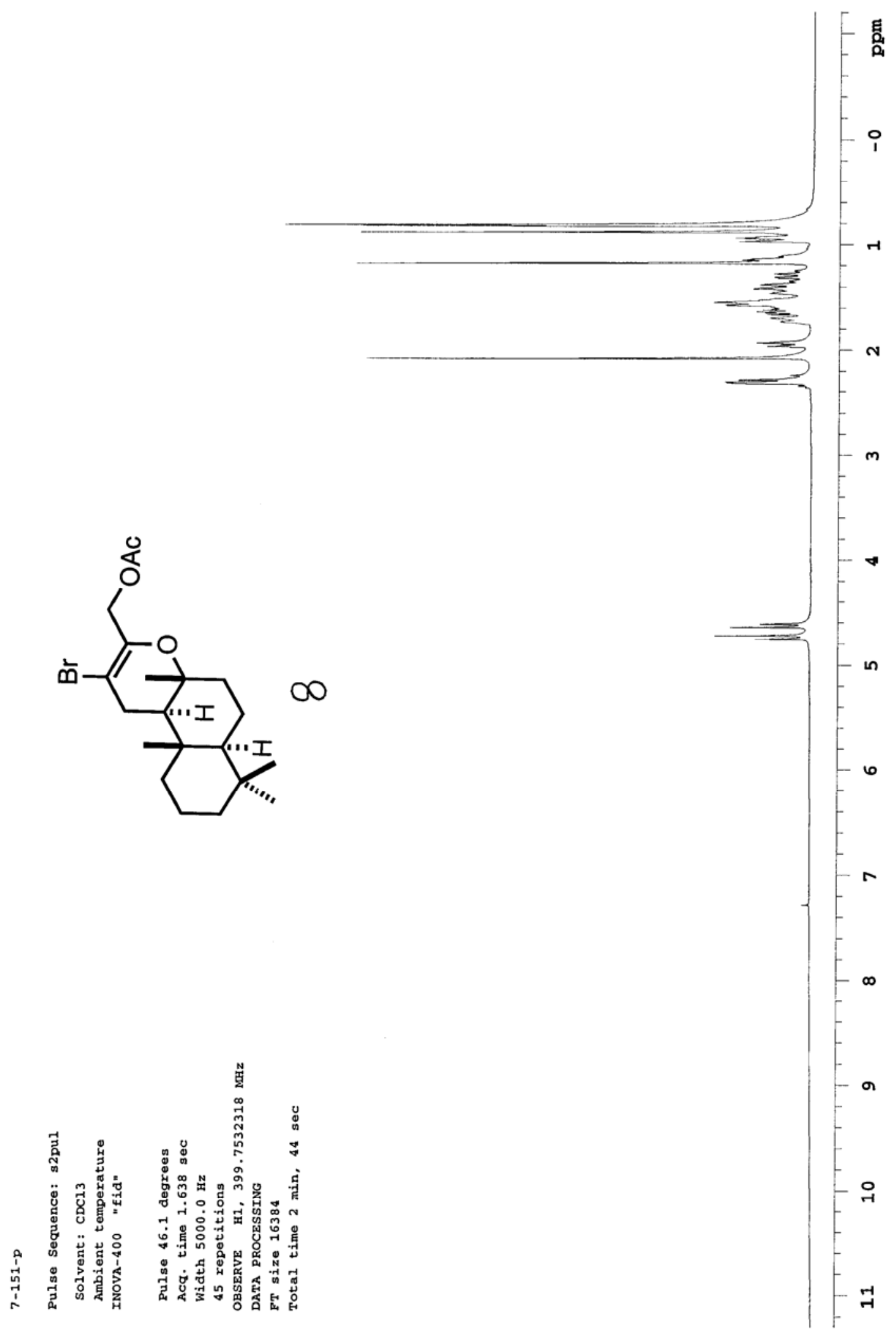



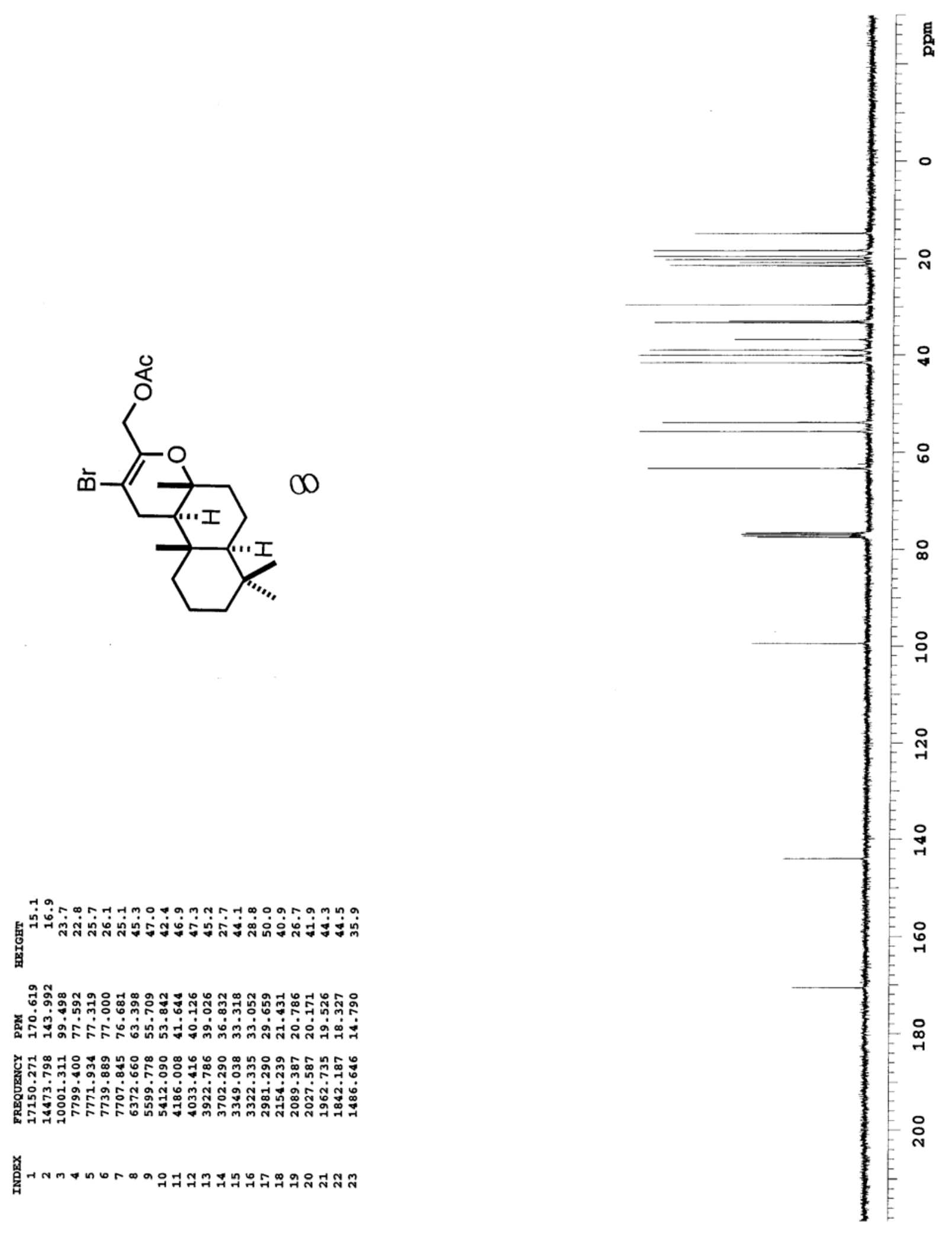


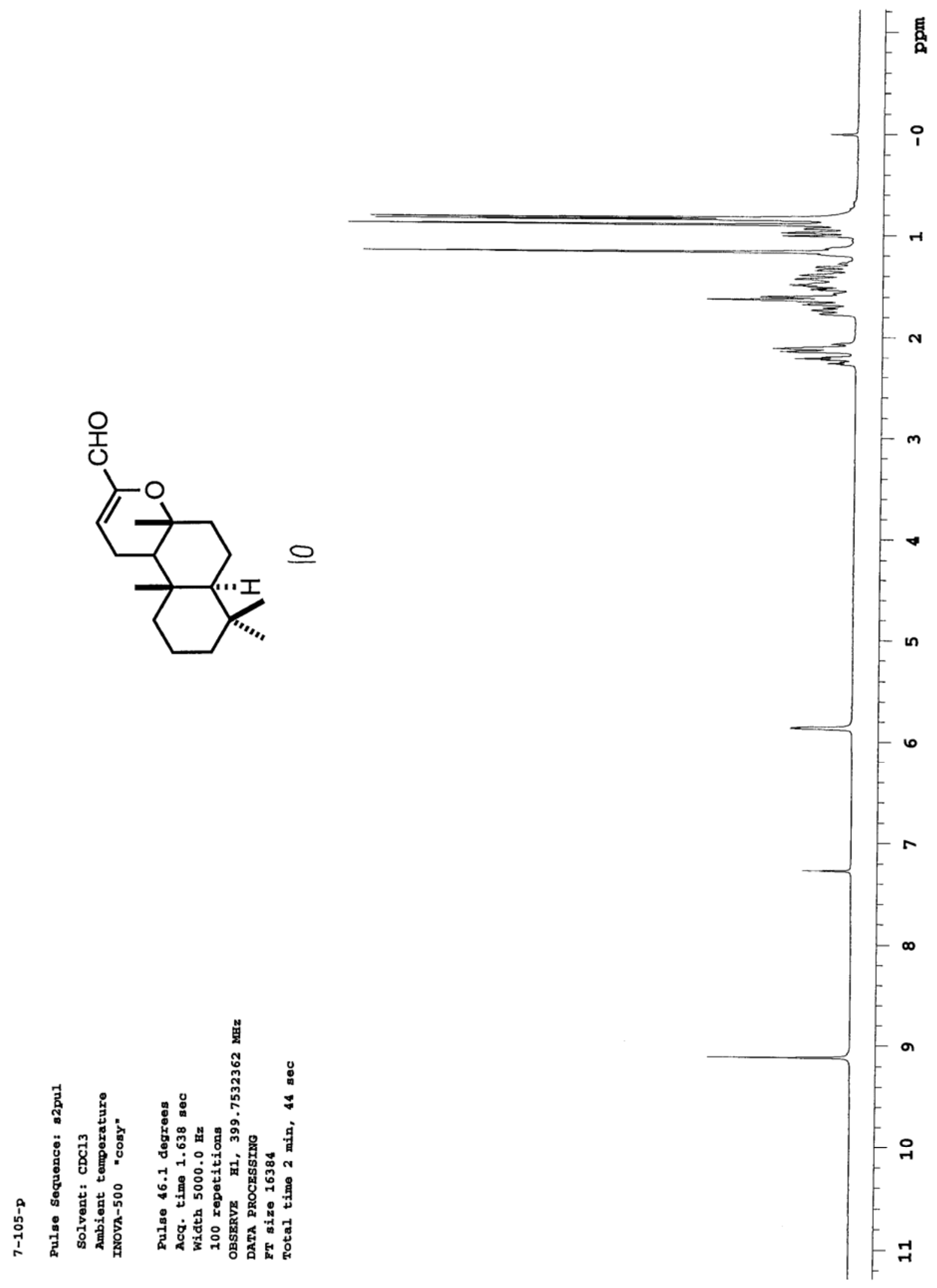




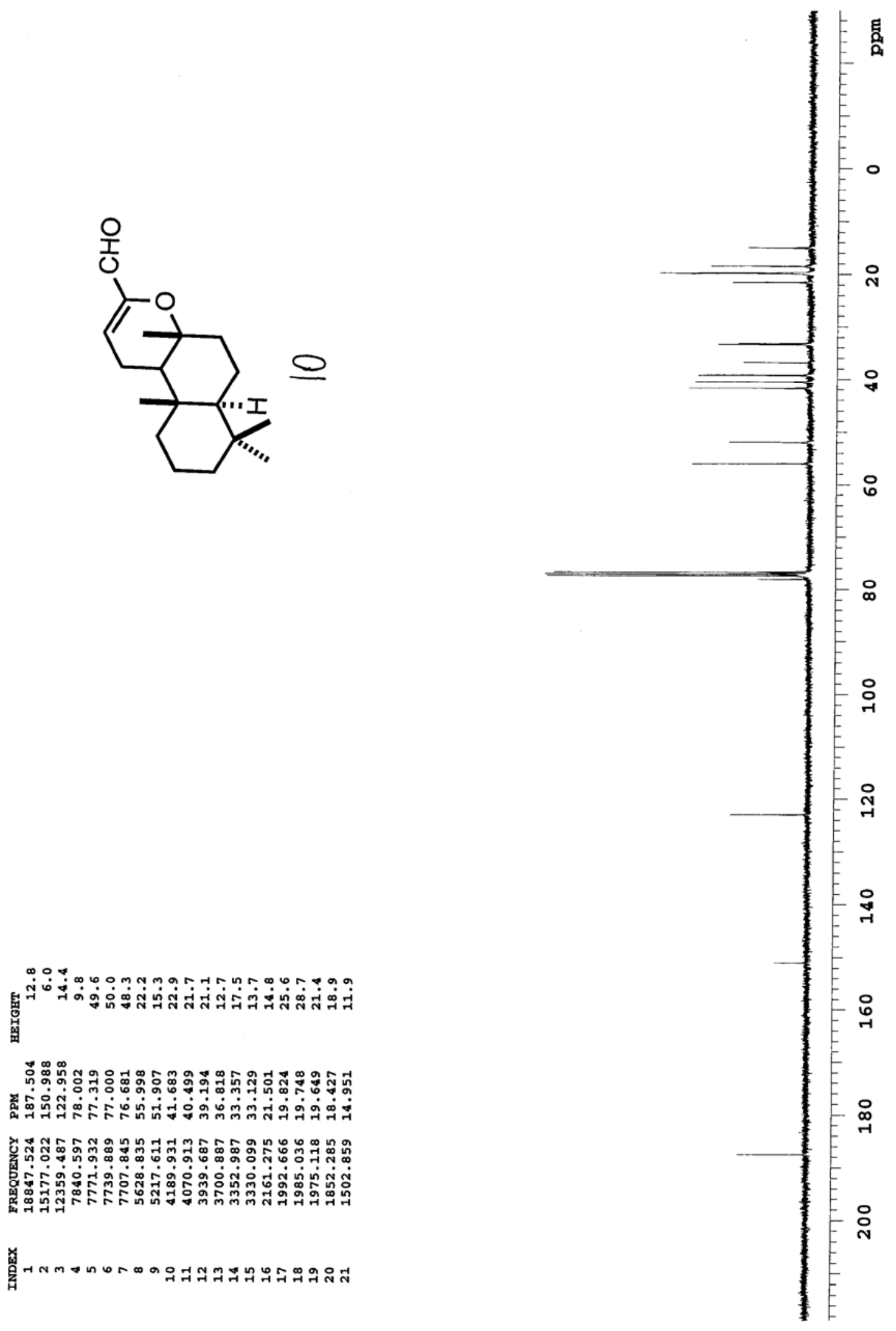




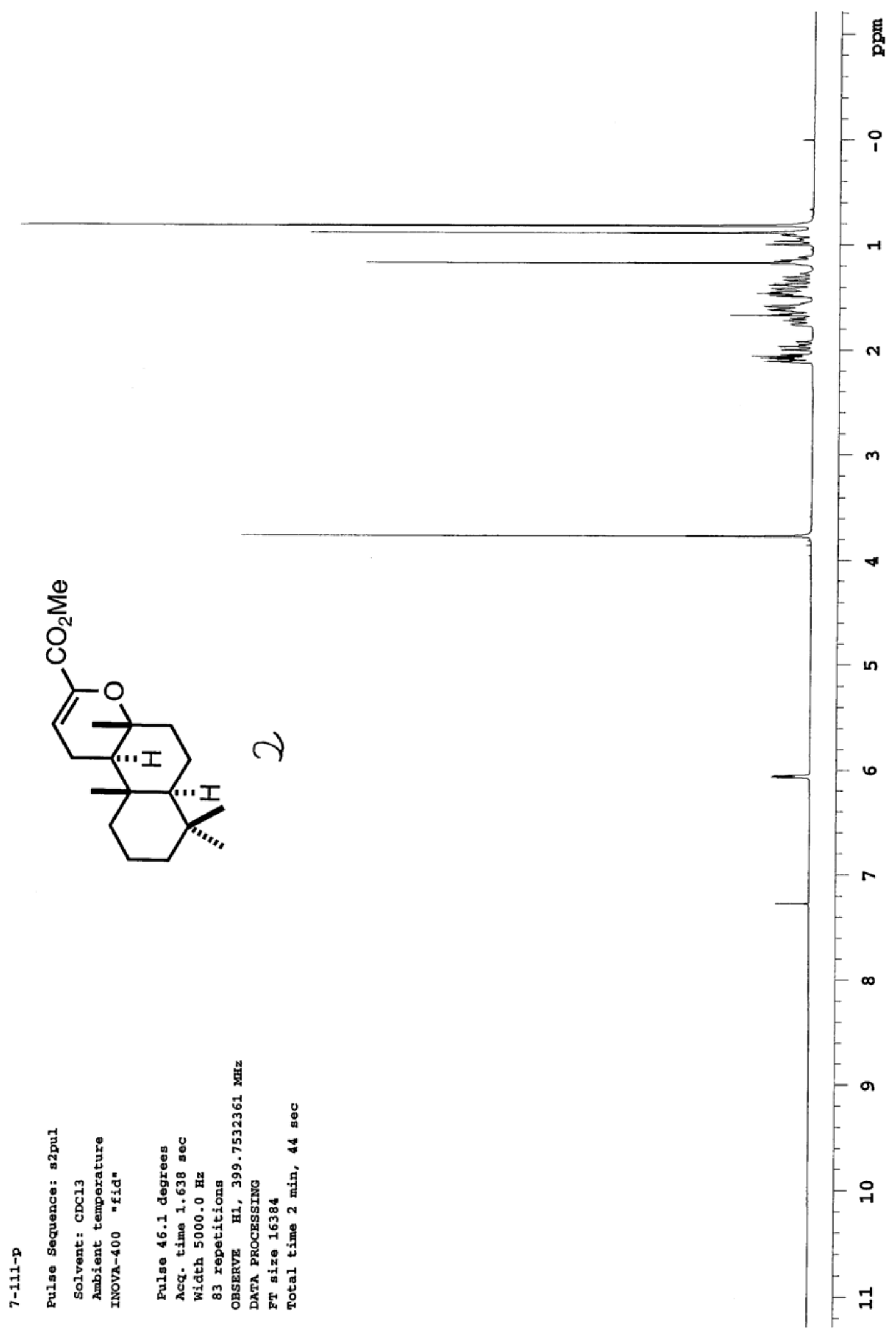



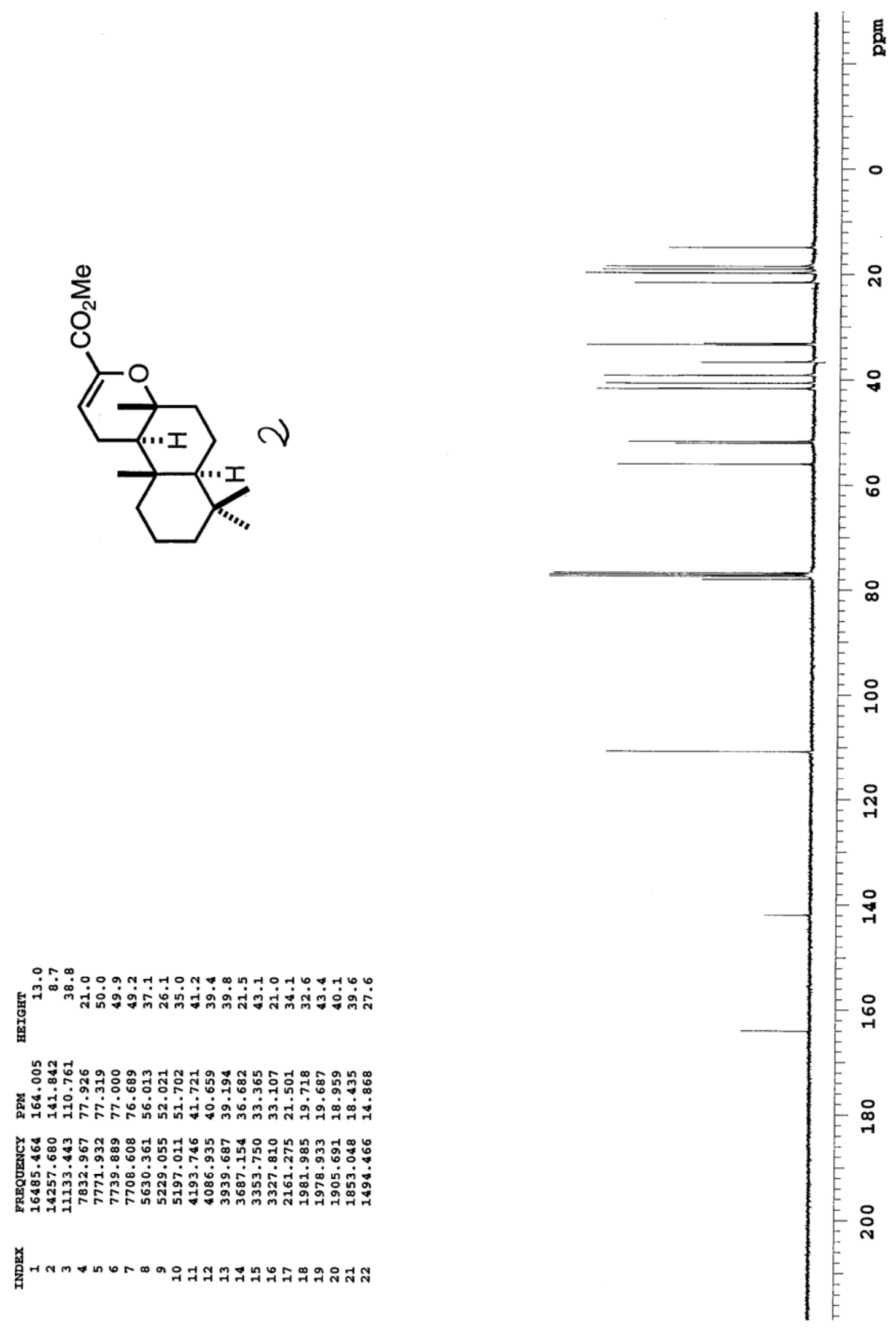


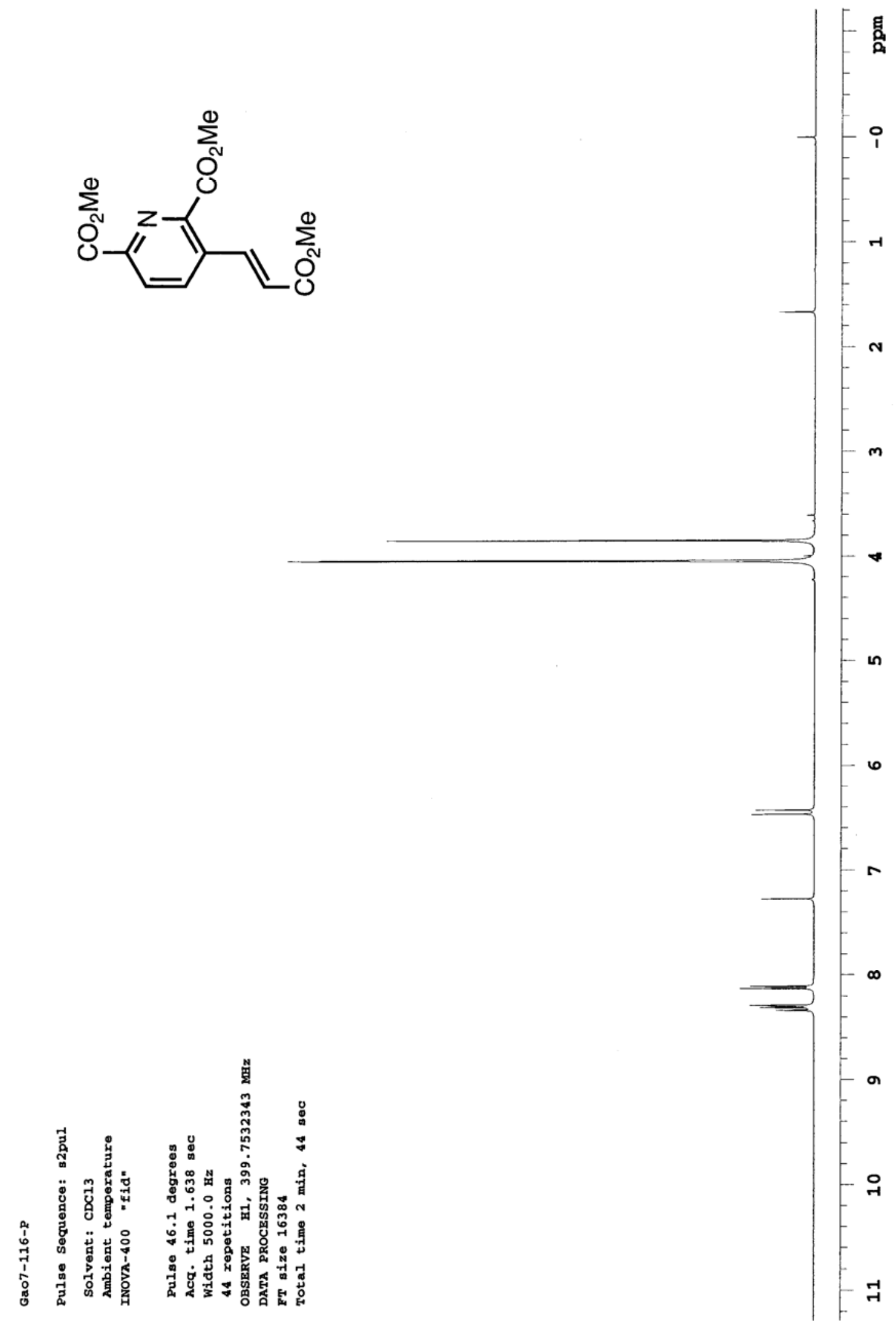



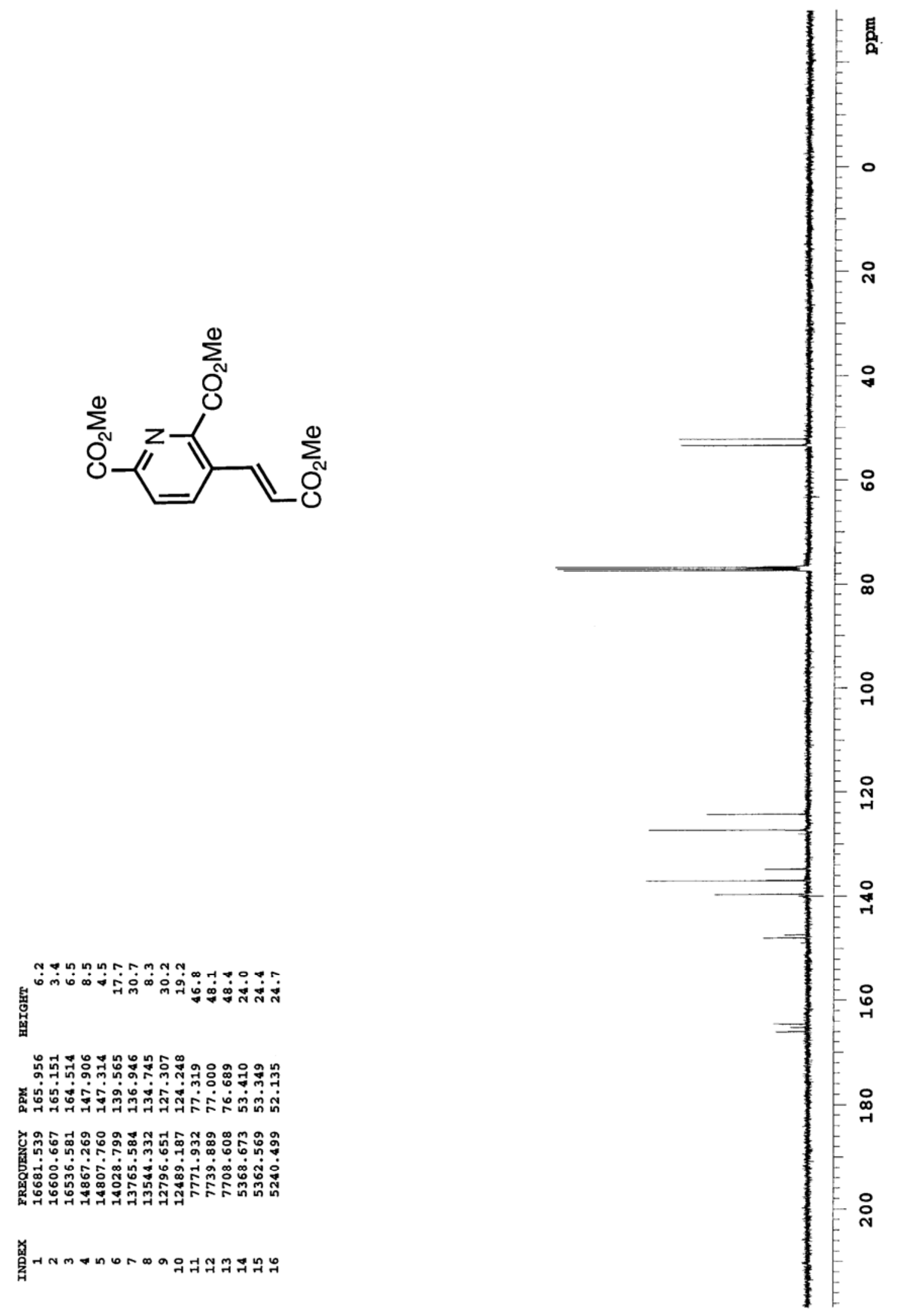


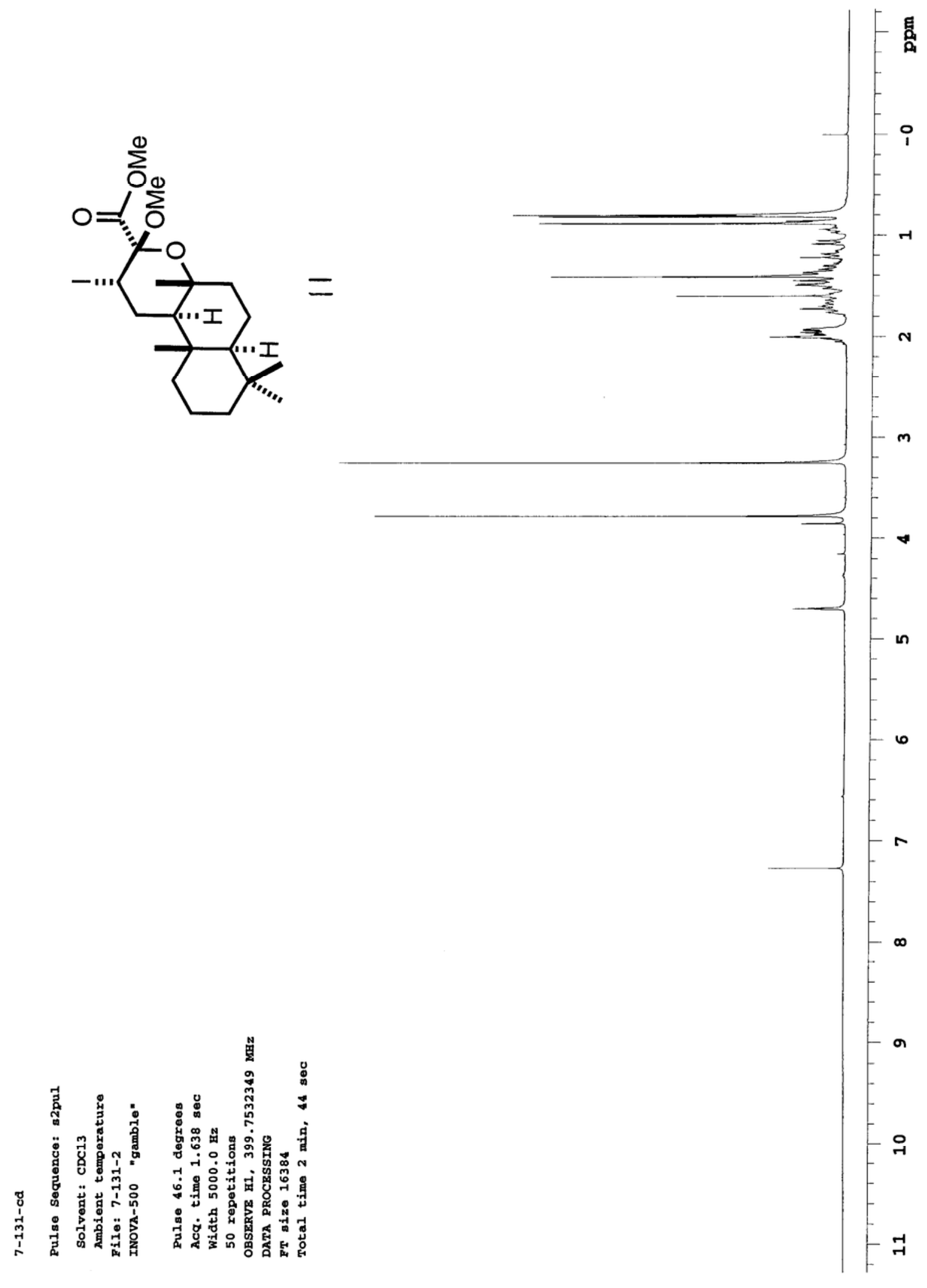




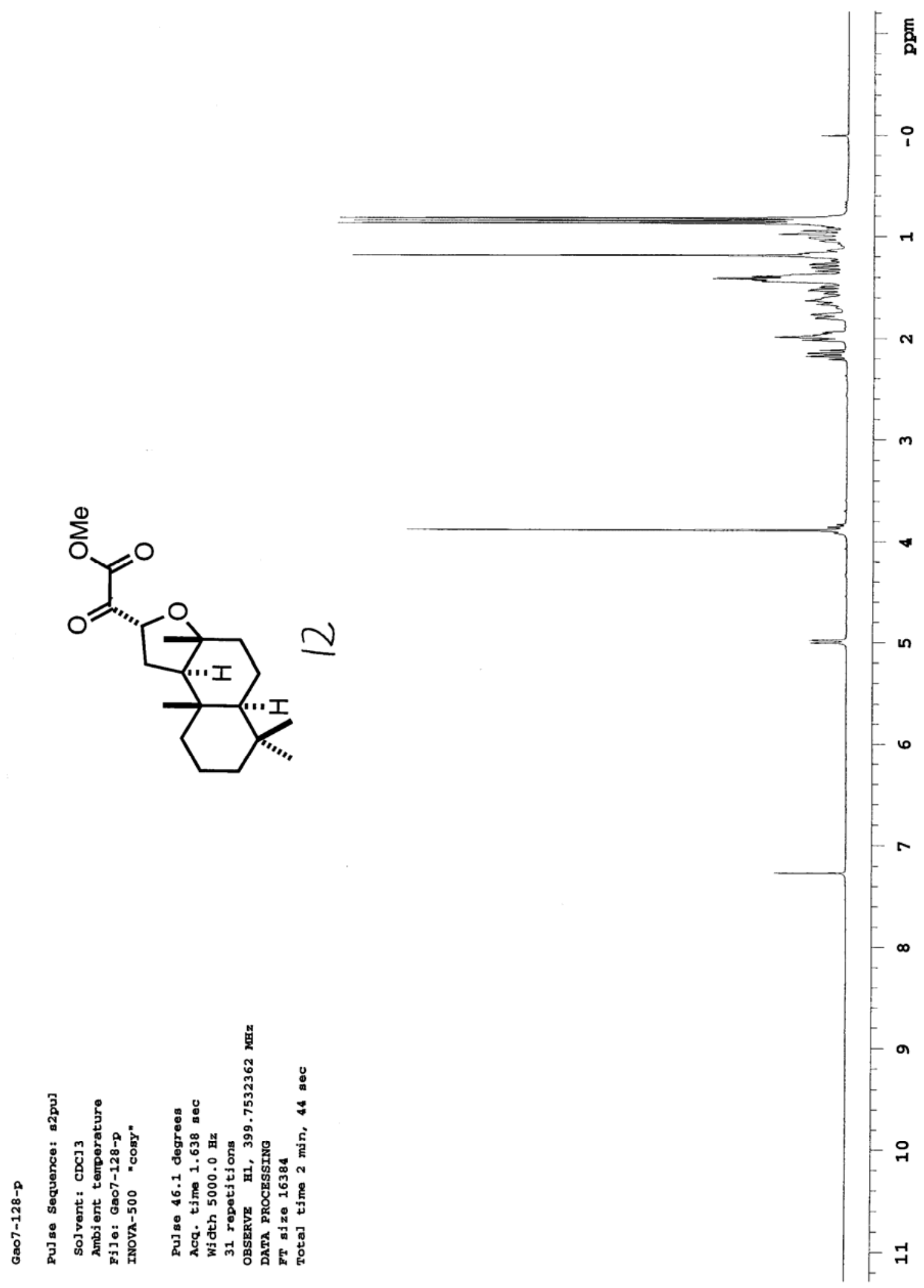




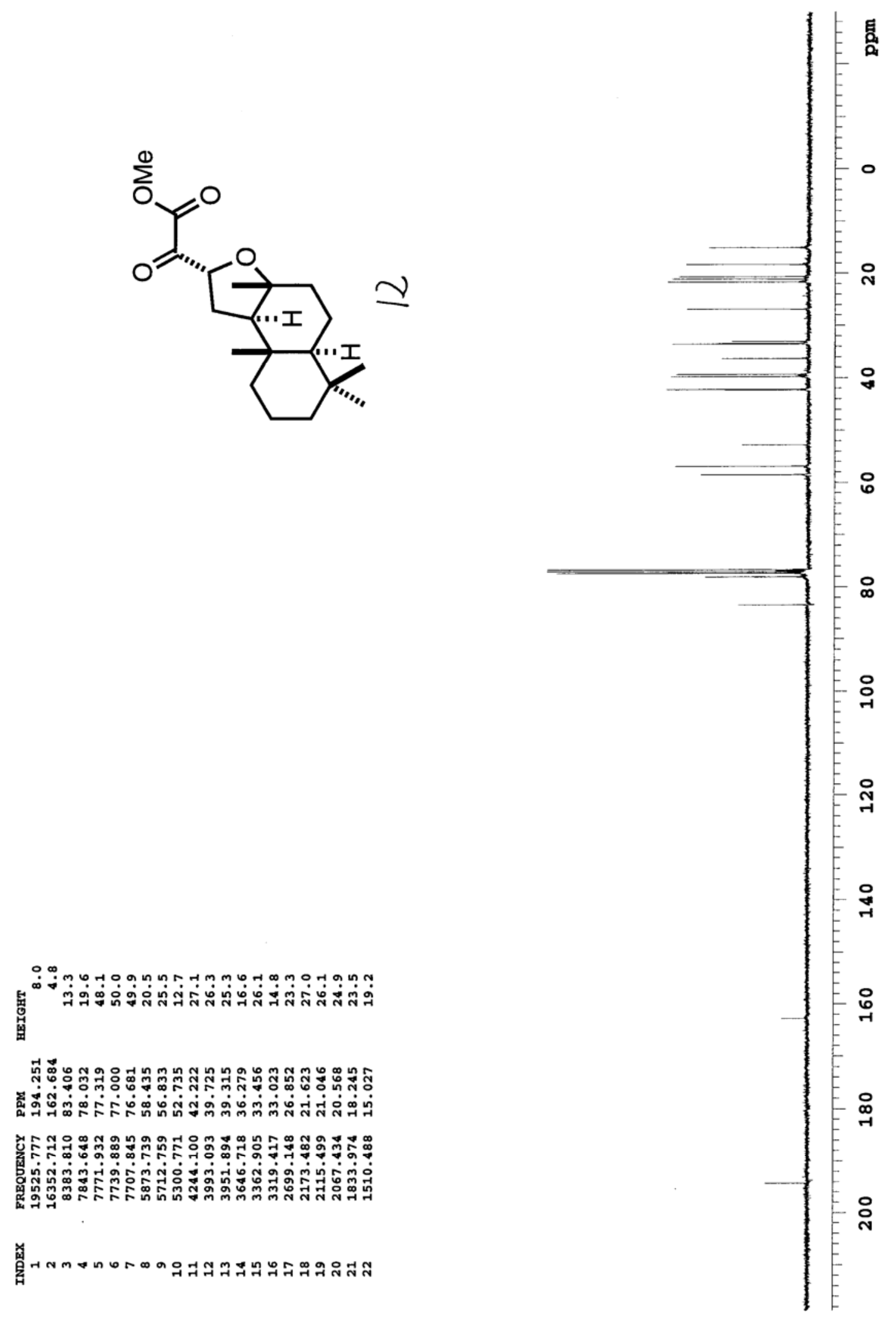




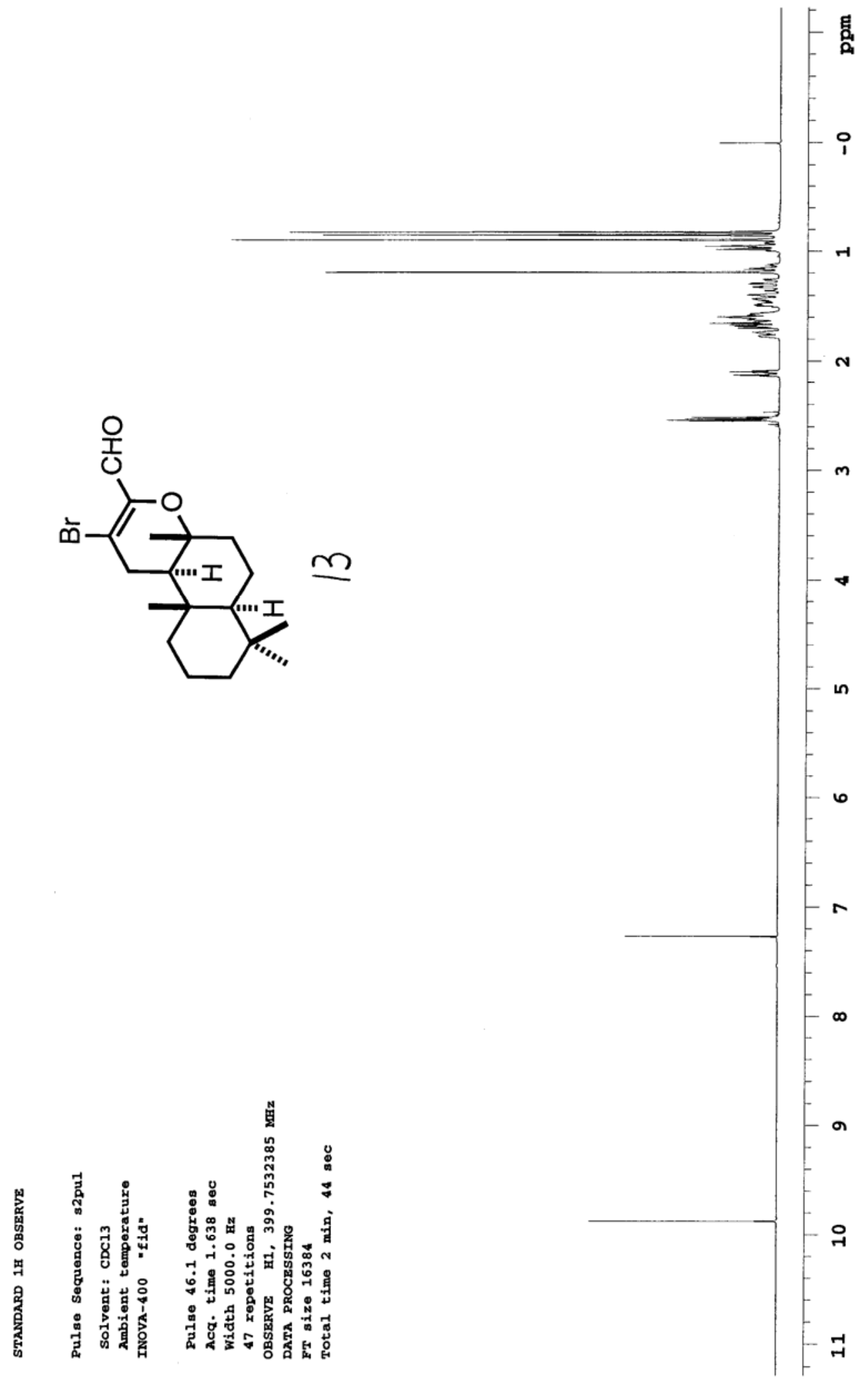




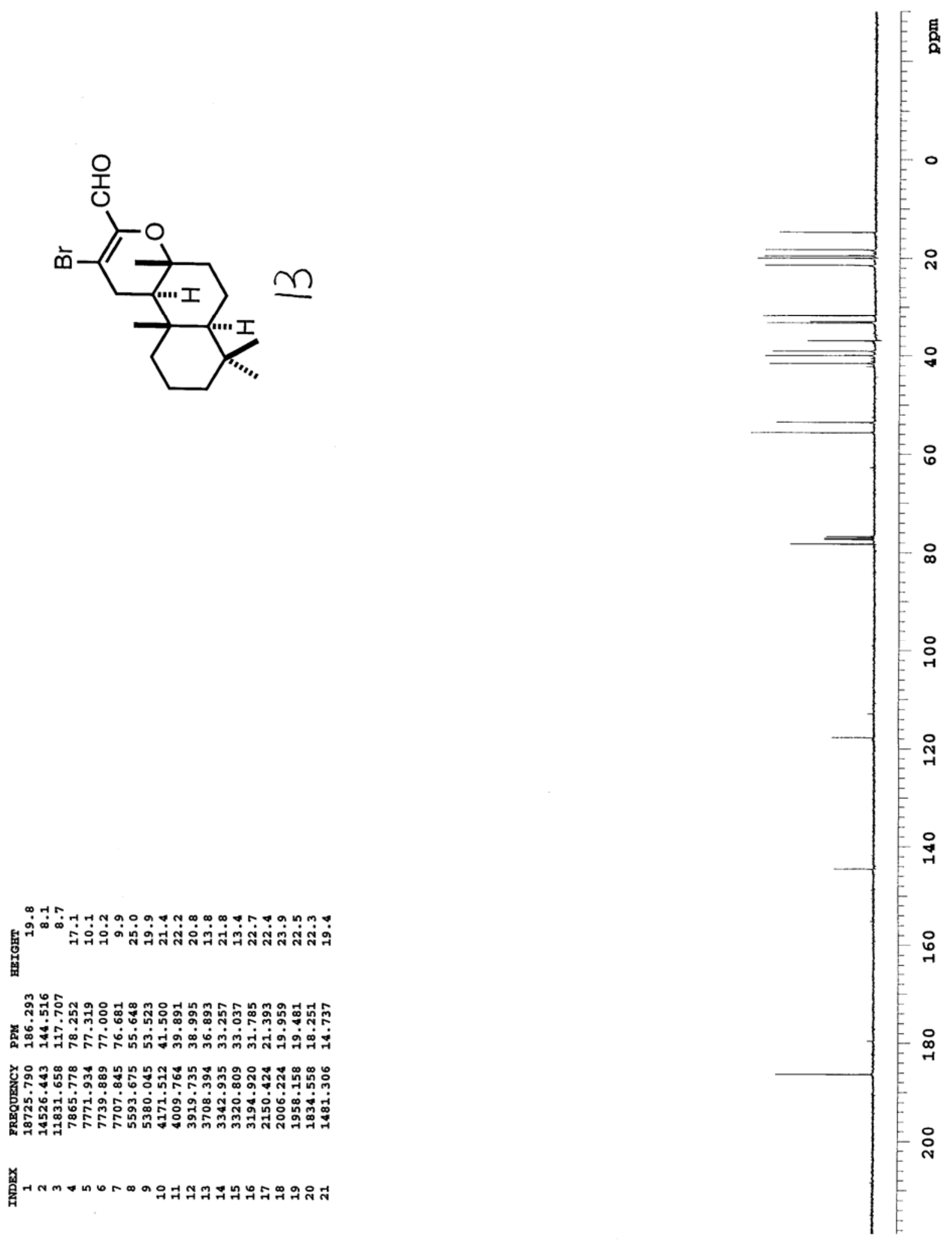




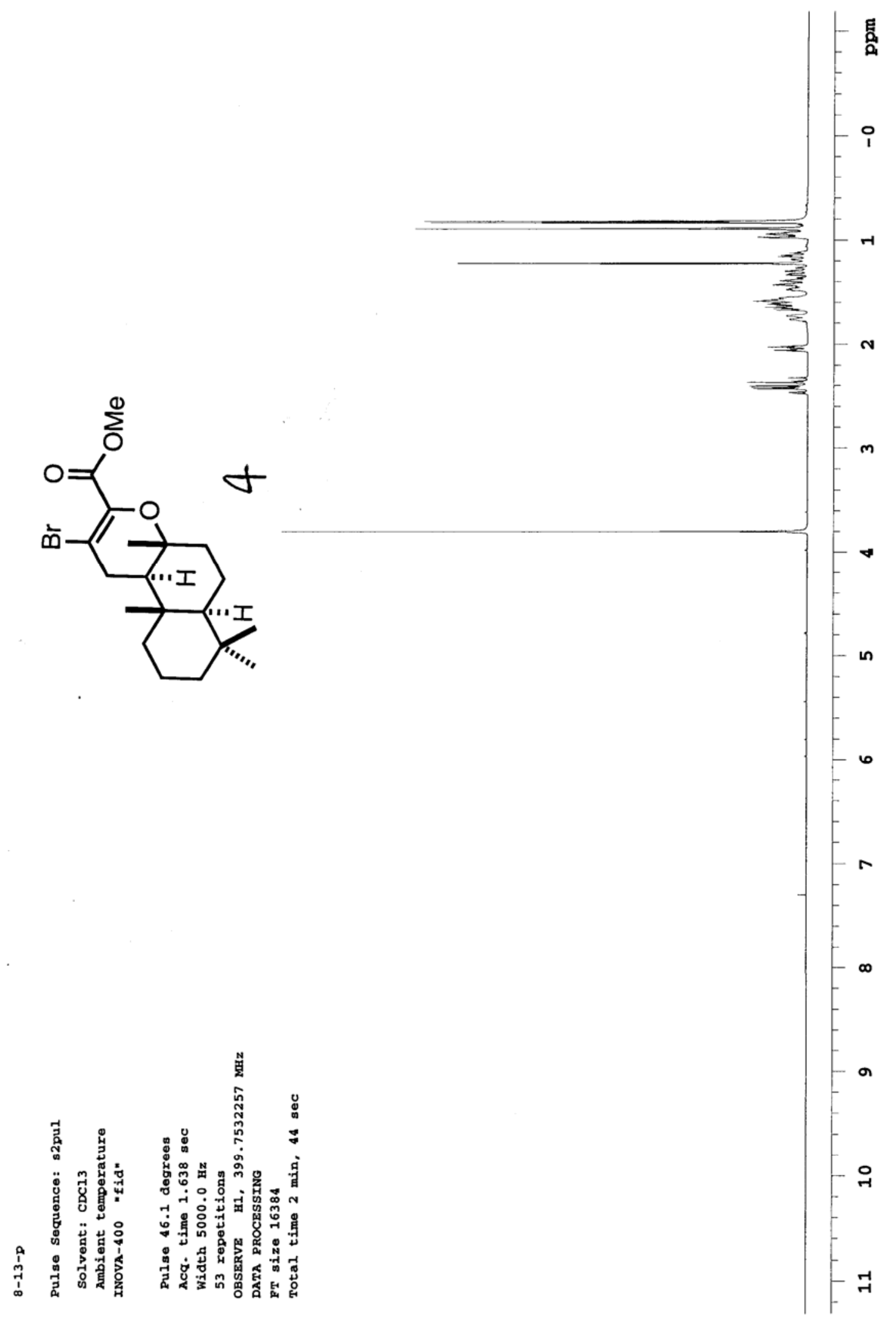




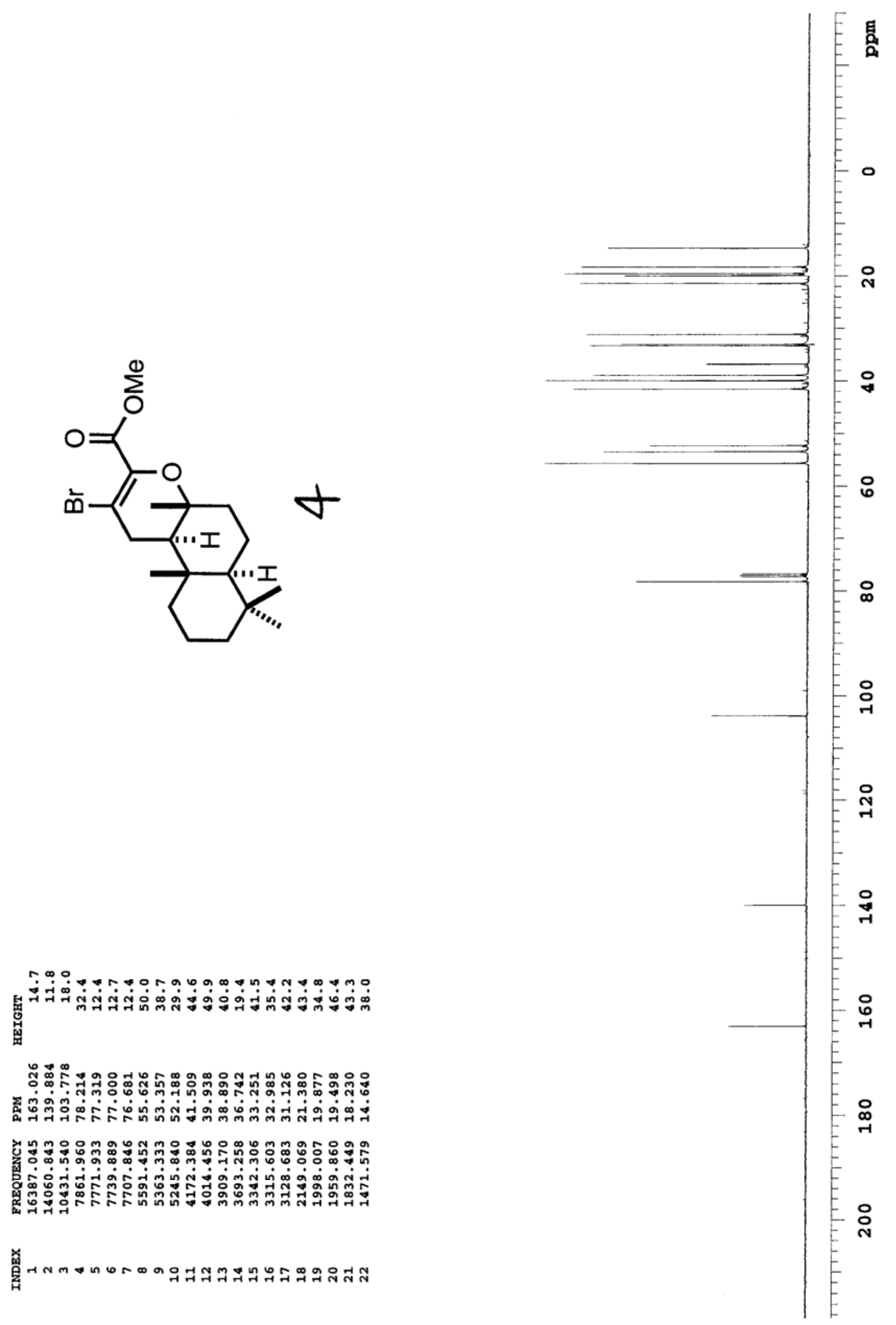




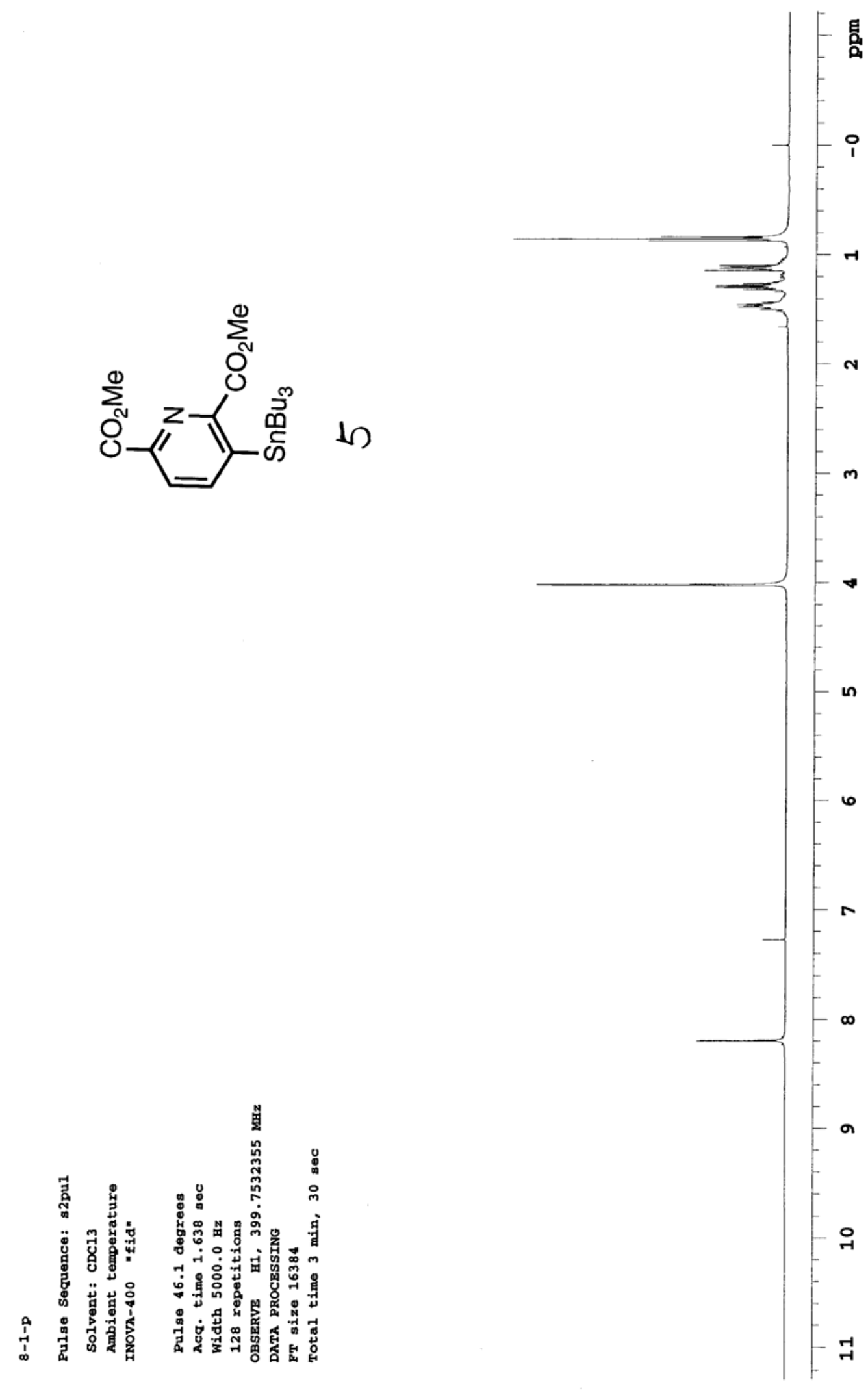




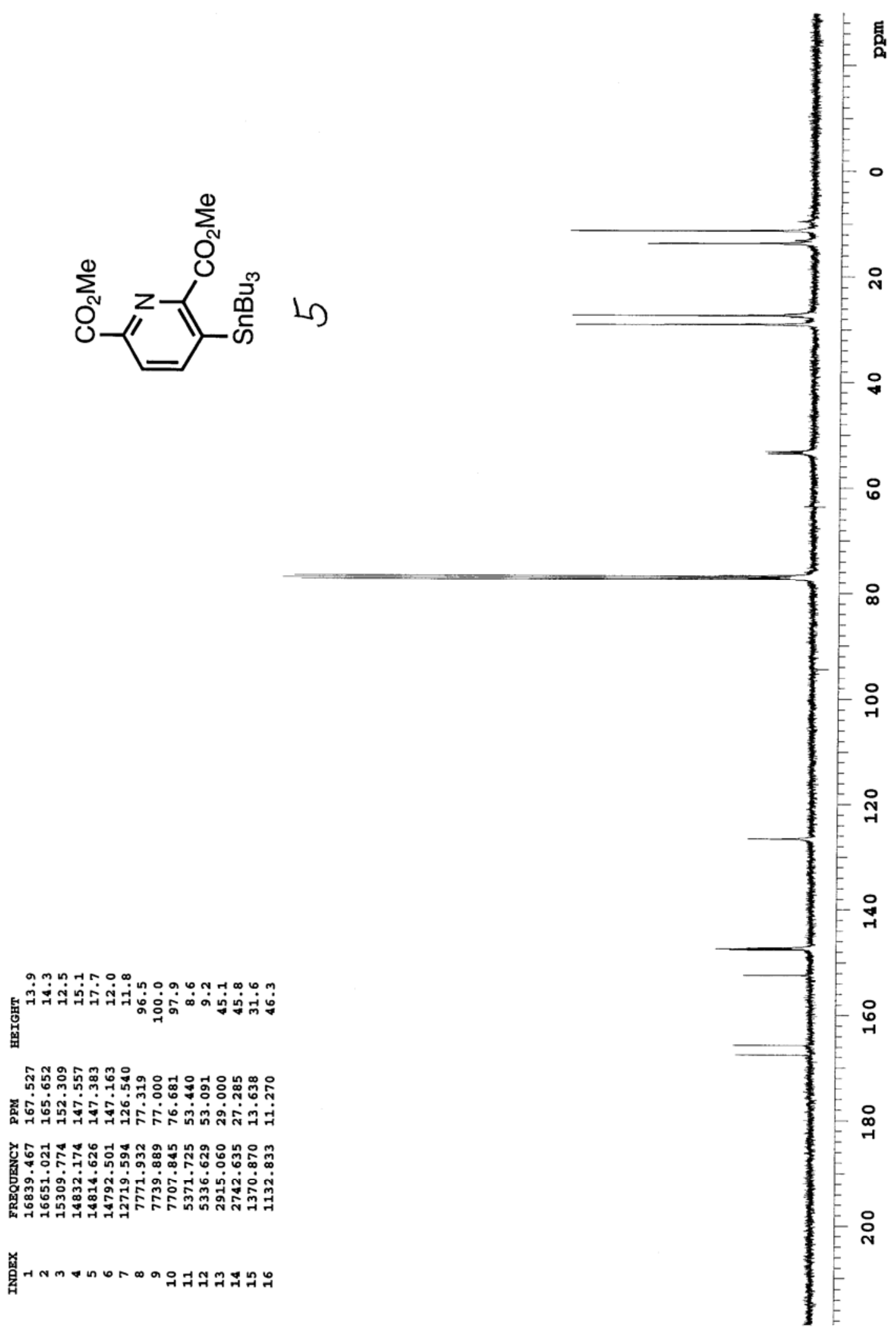



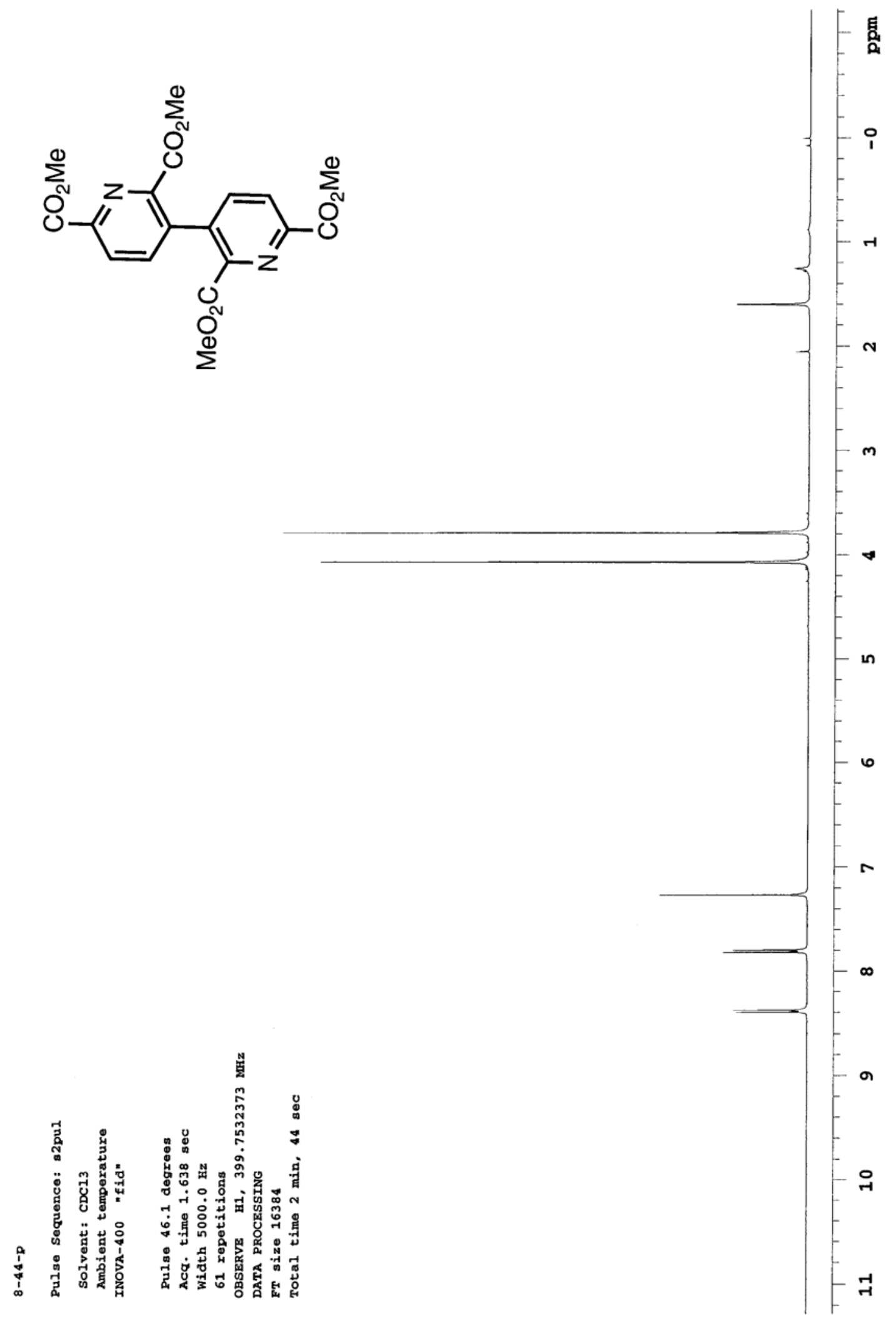


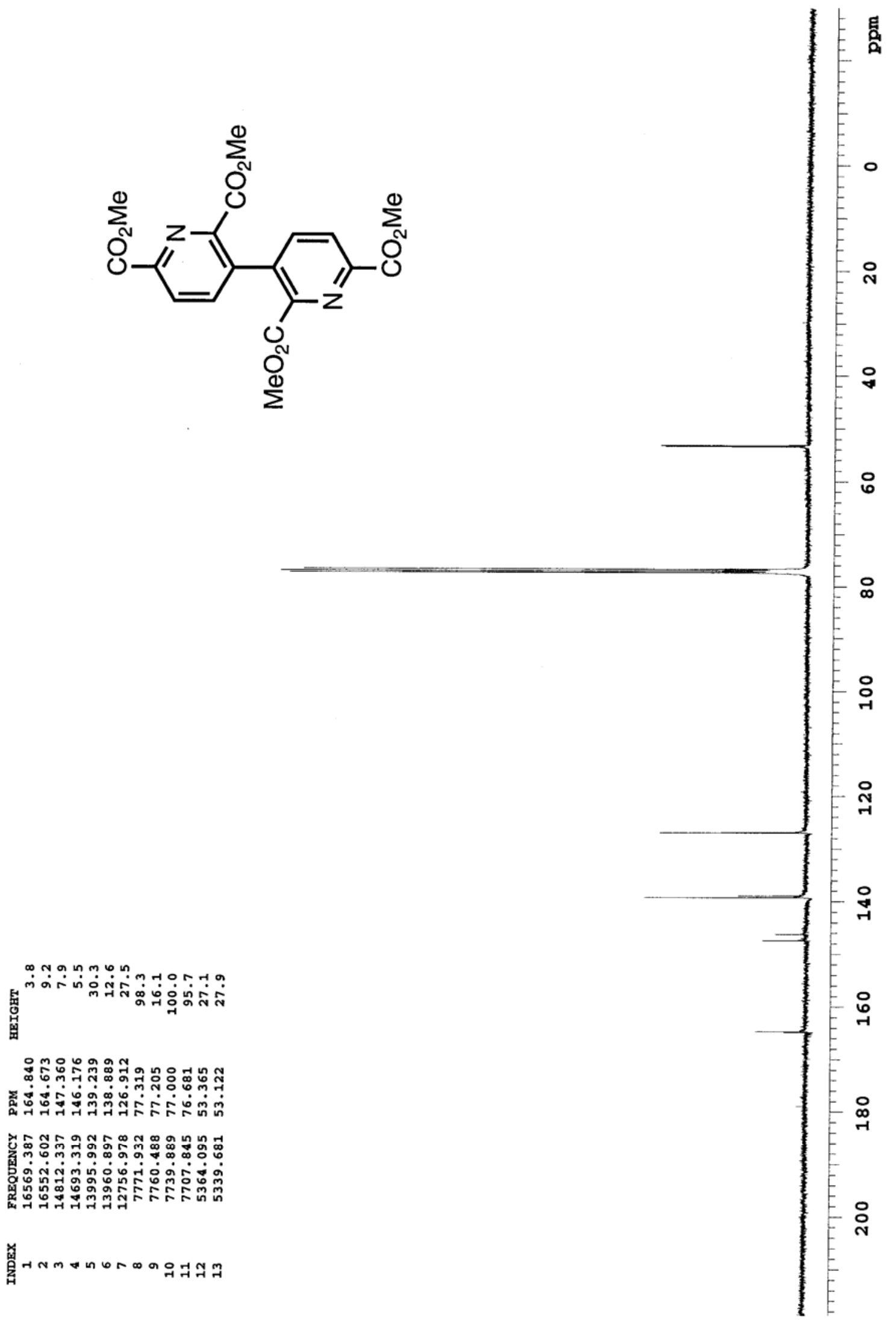




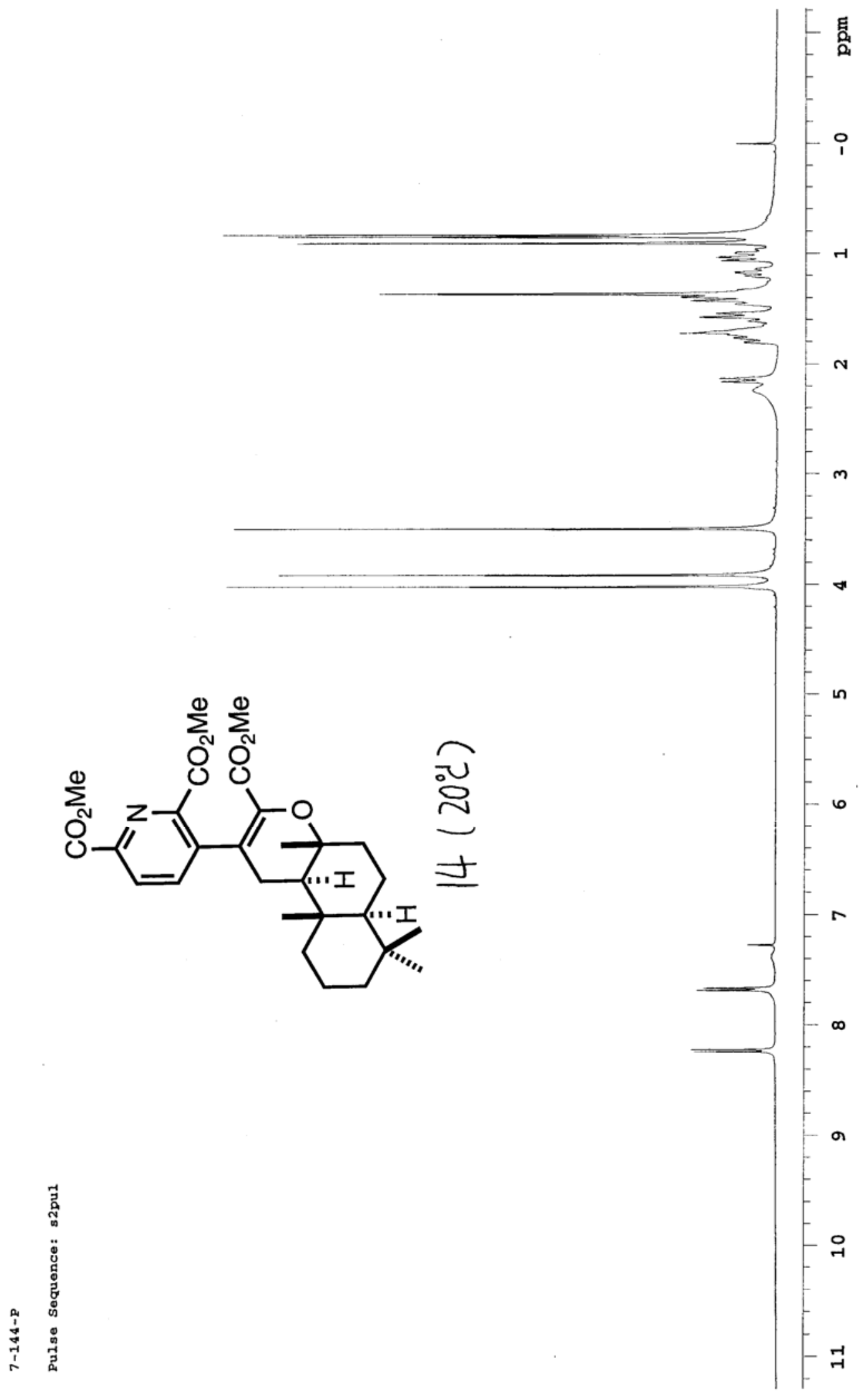




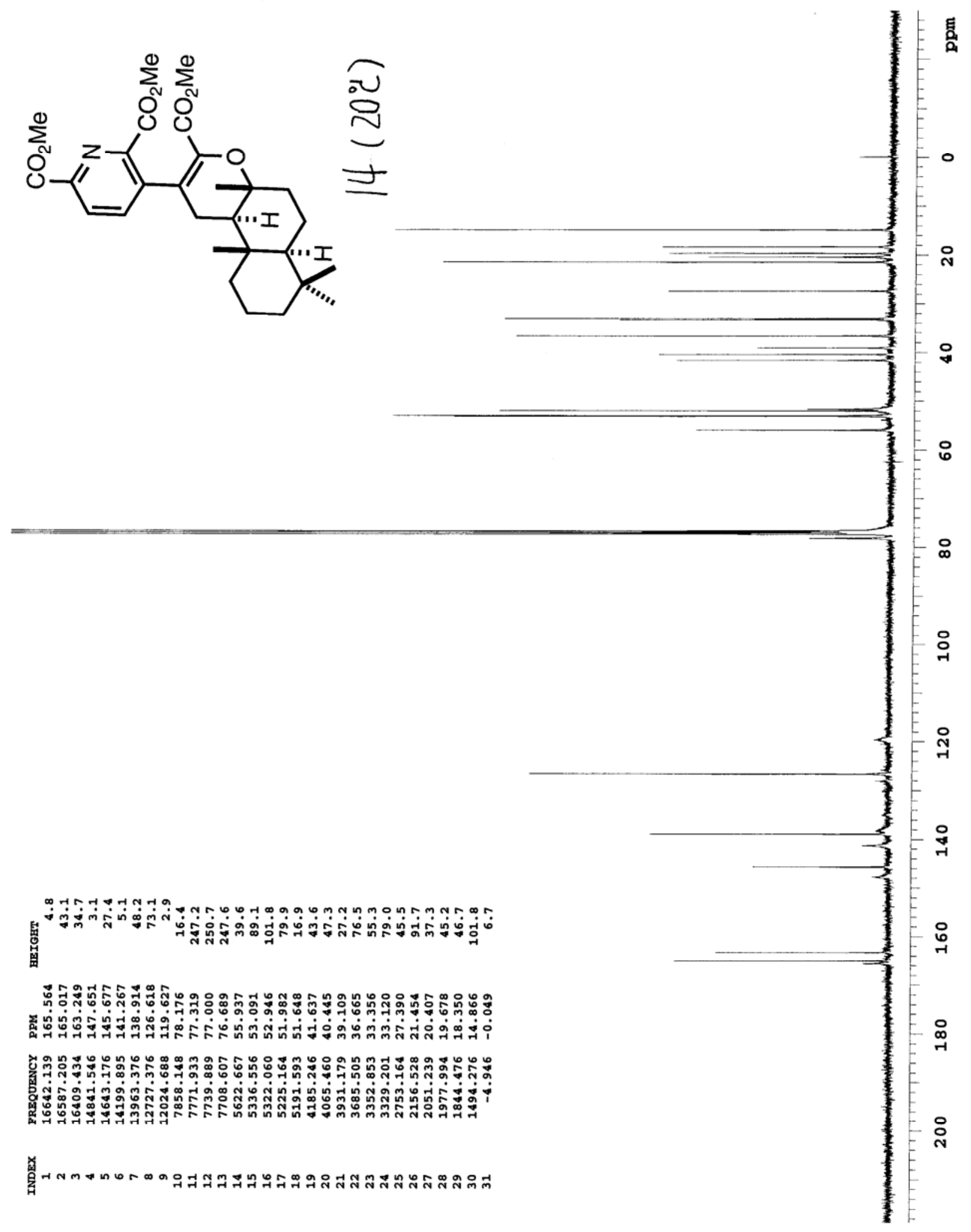




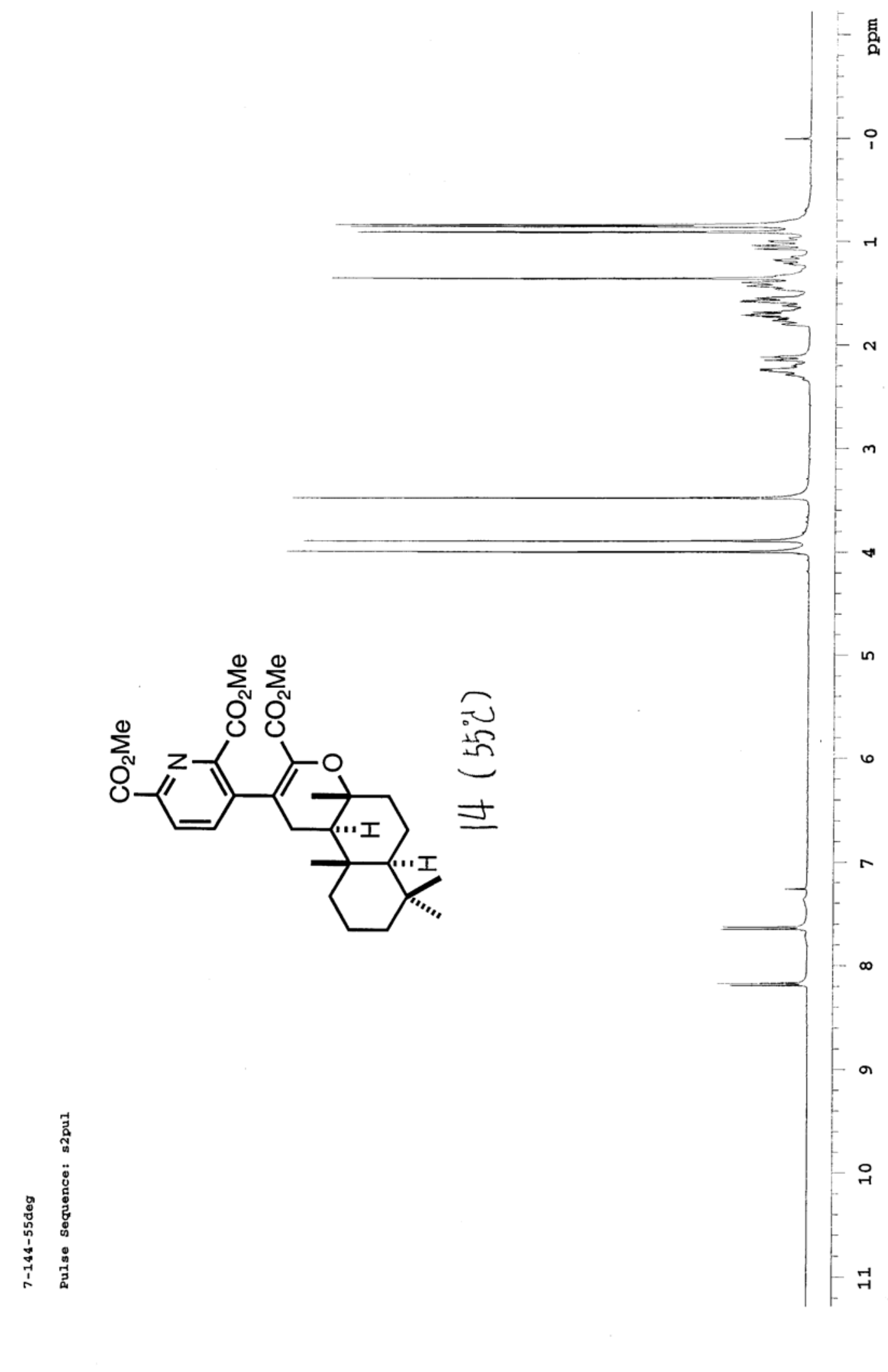




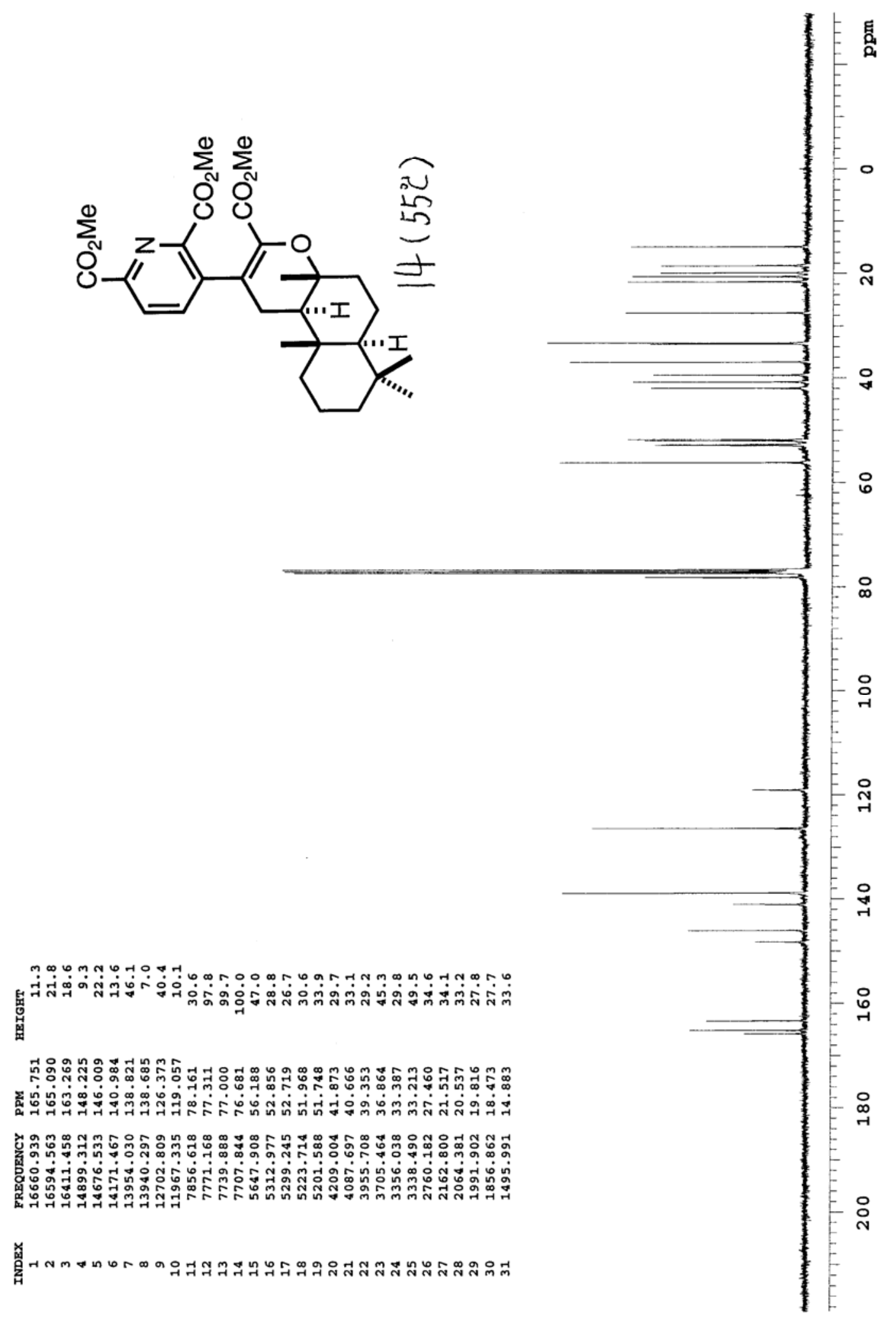




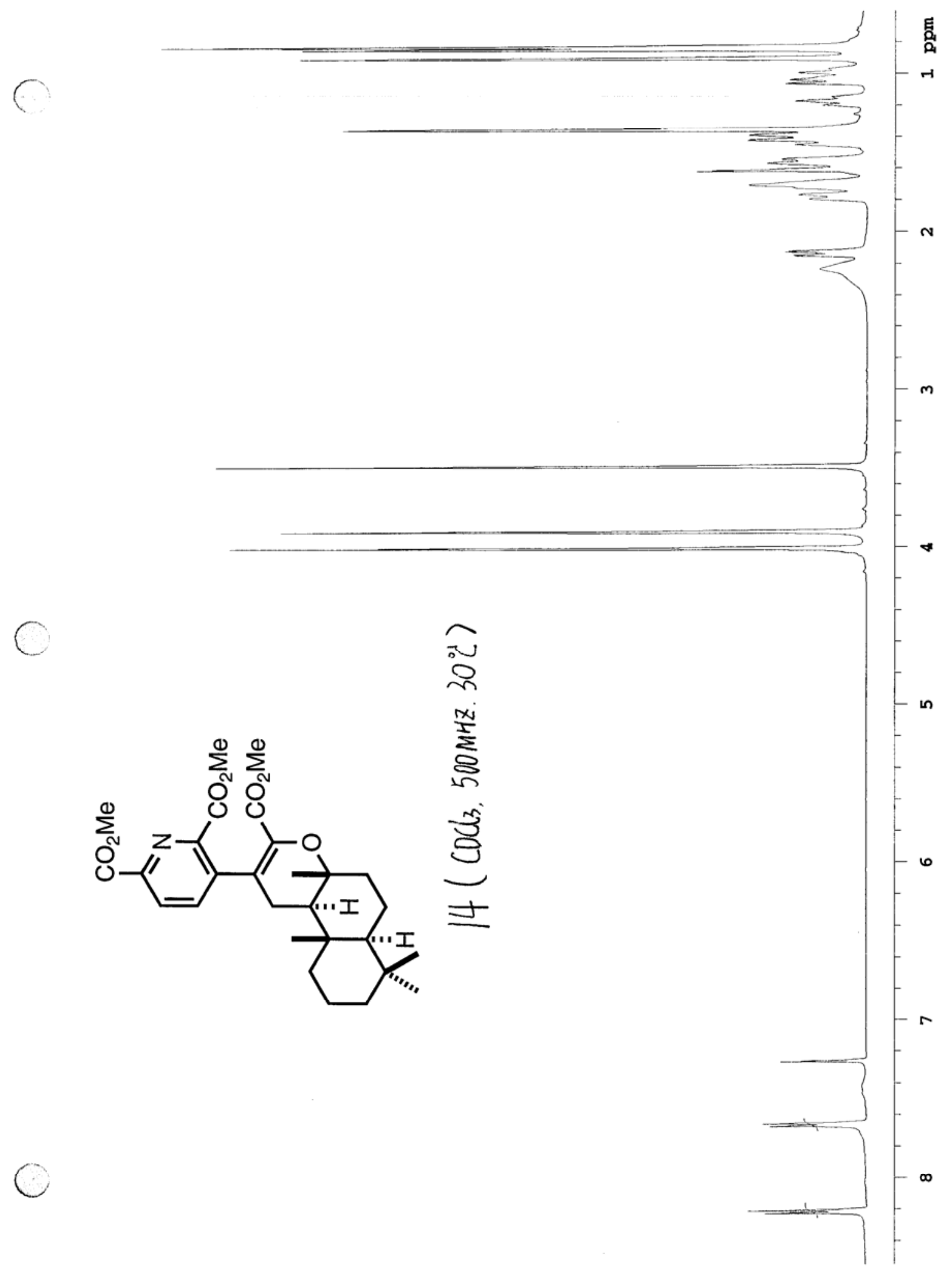




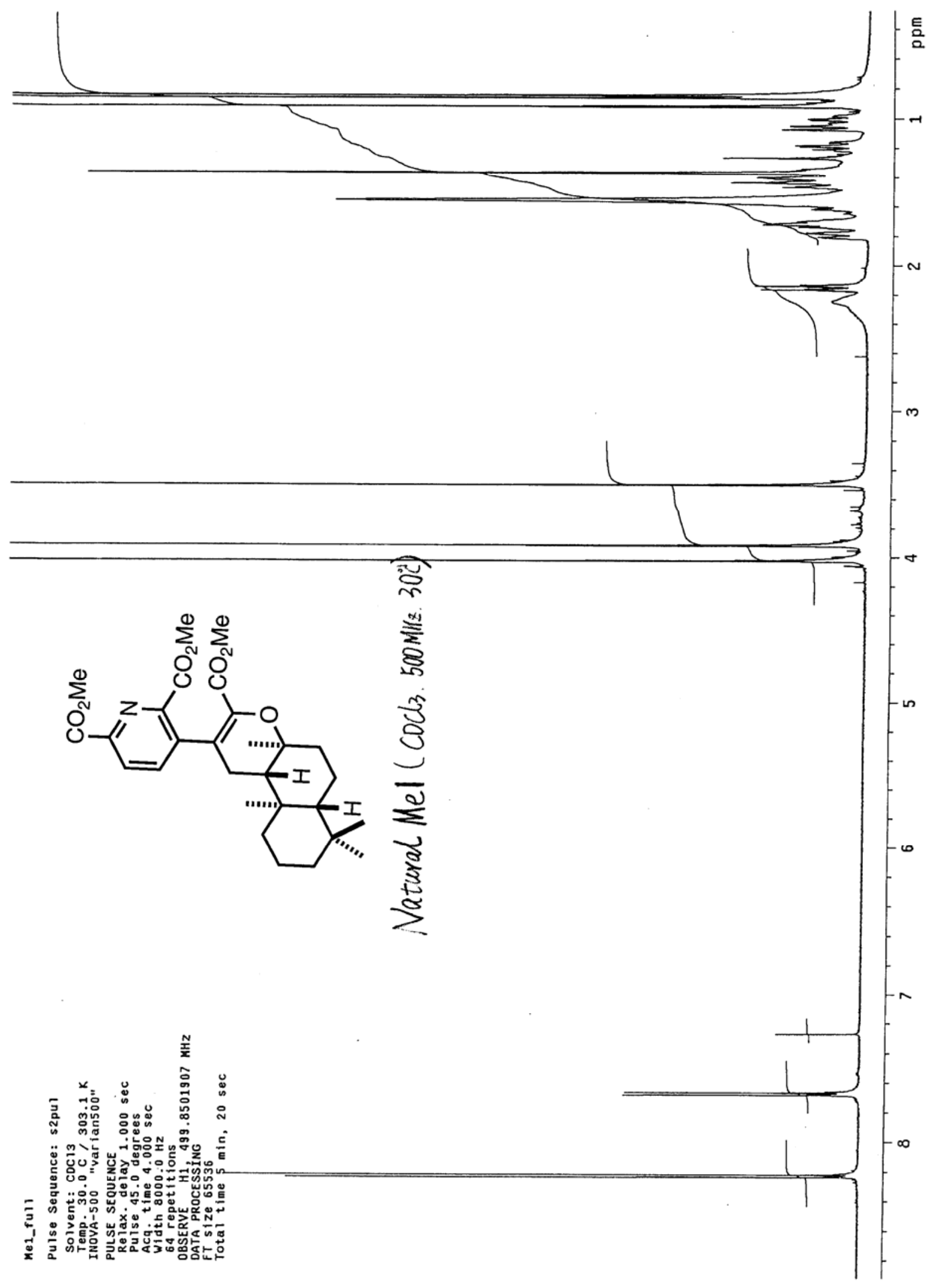




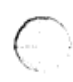

$\bigcirc$

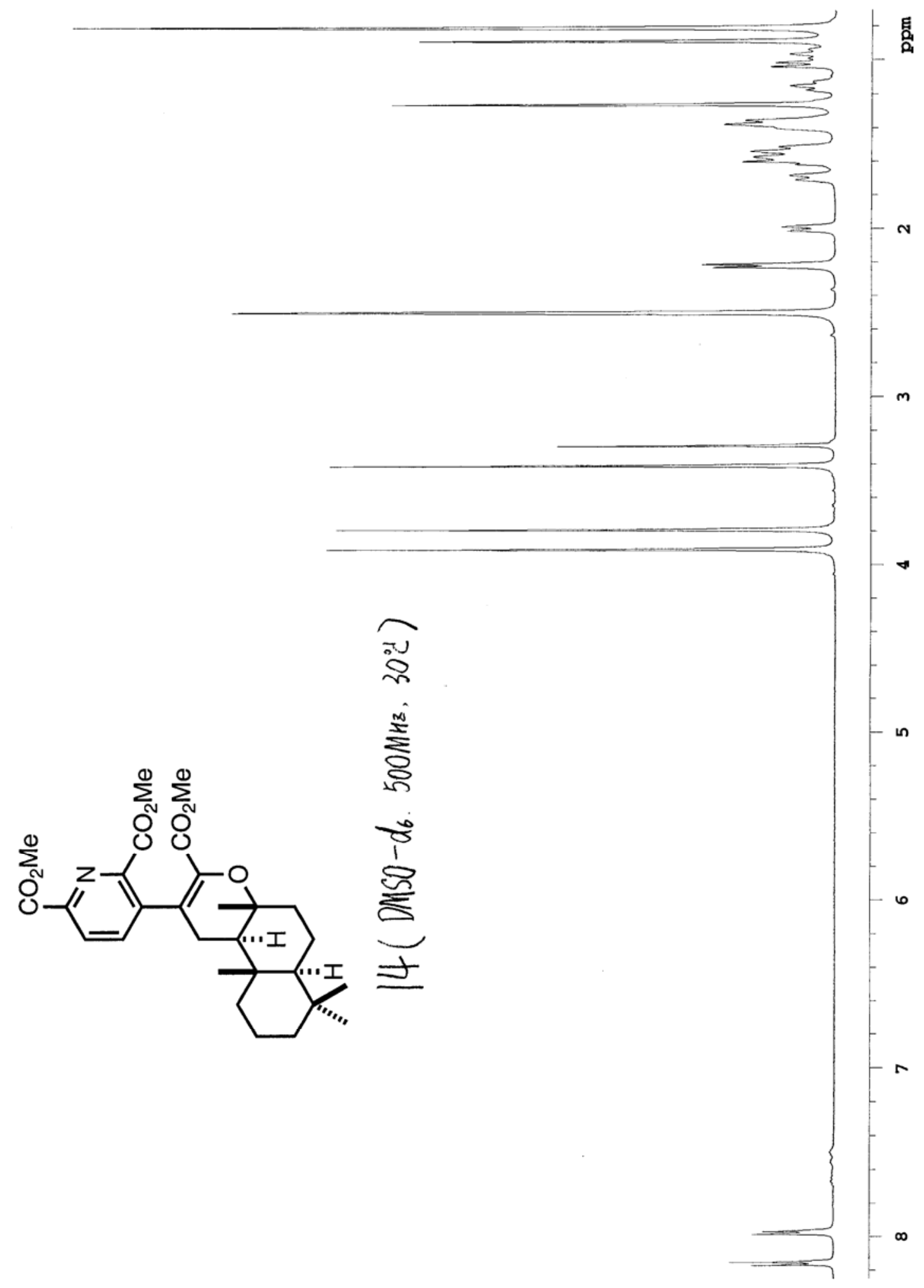




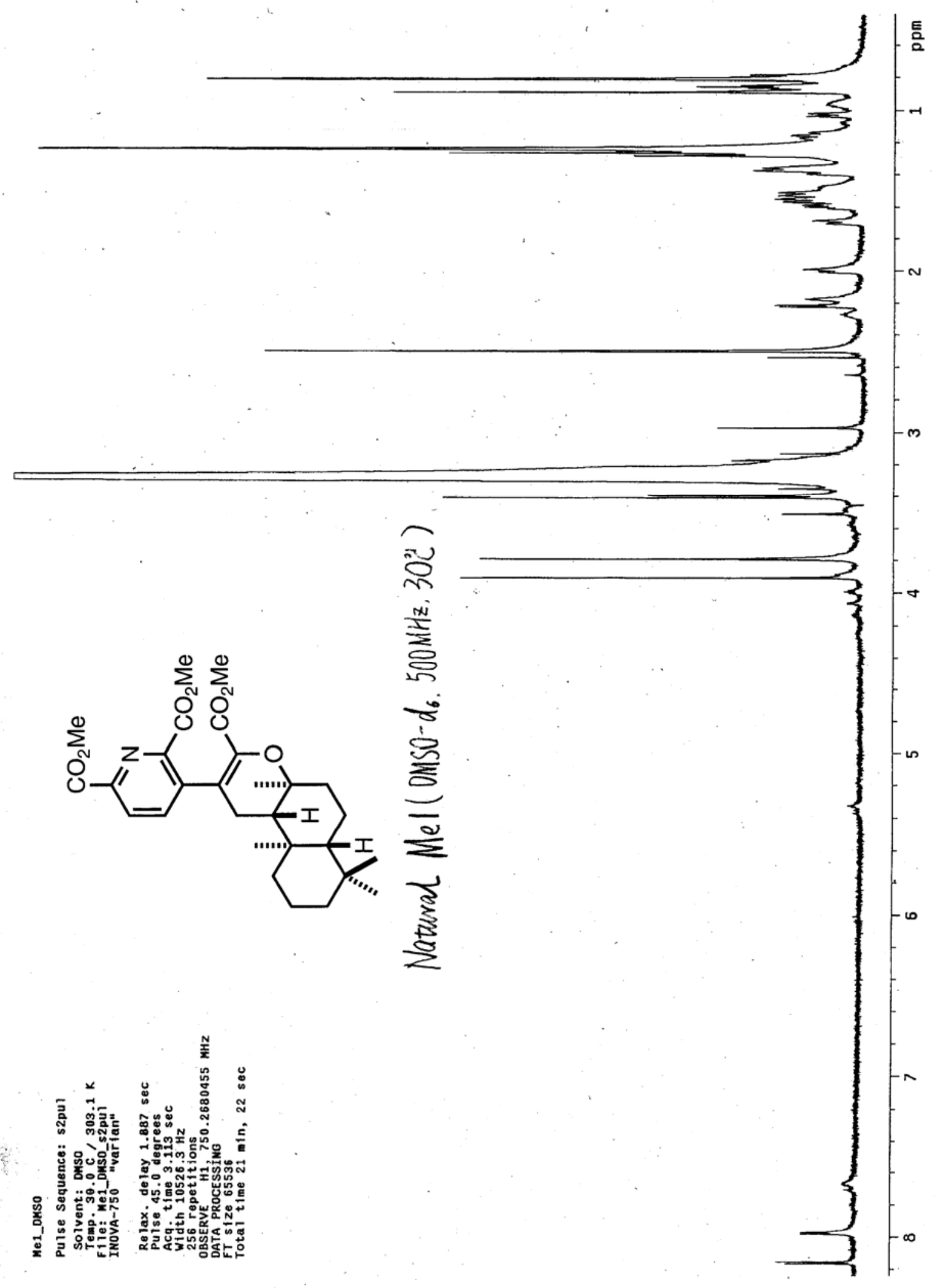




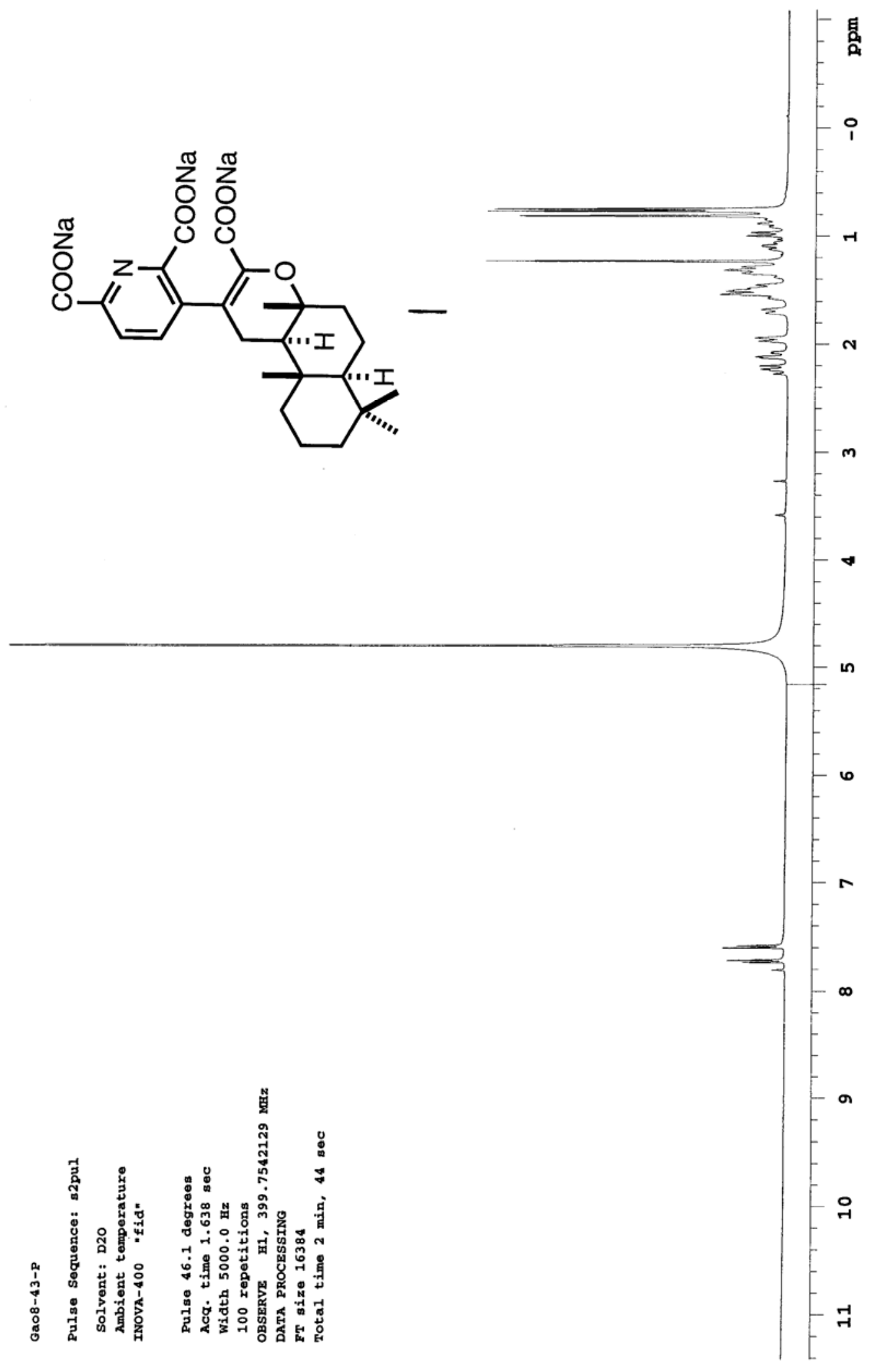



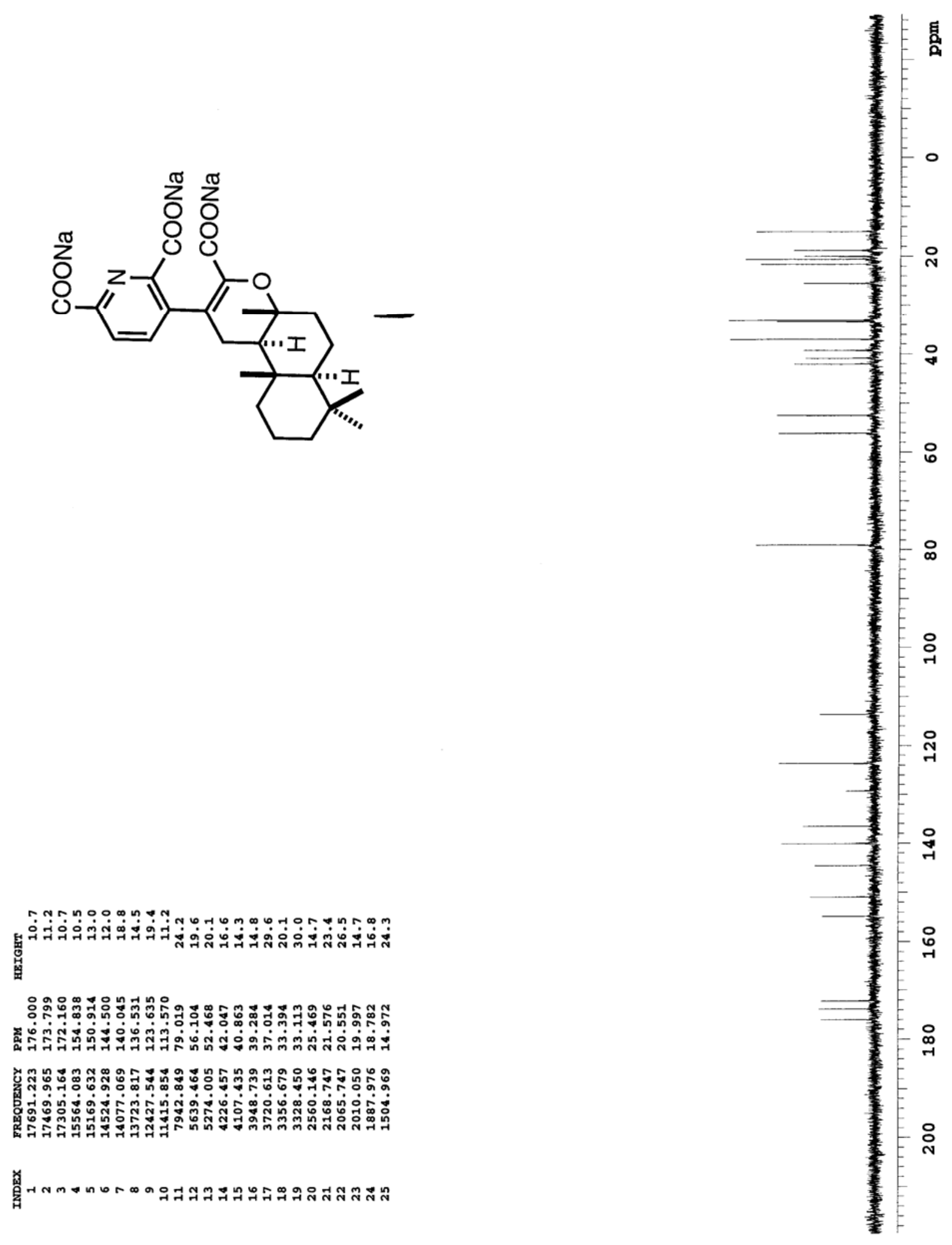


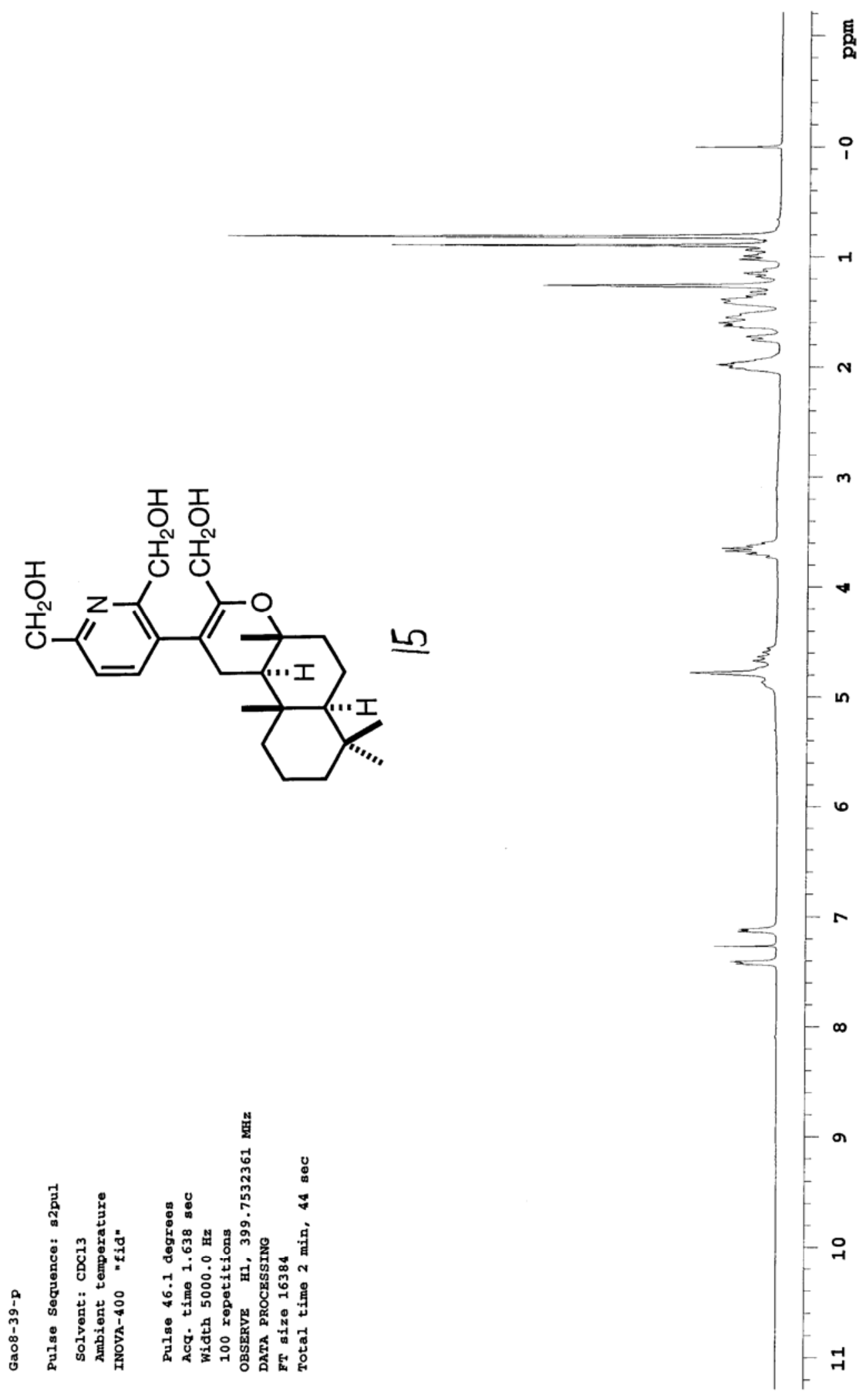




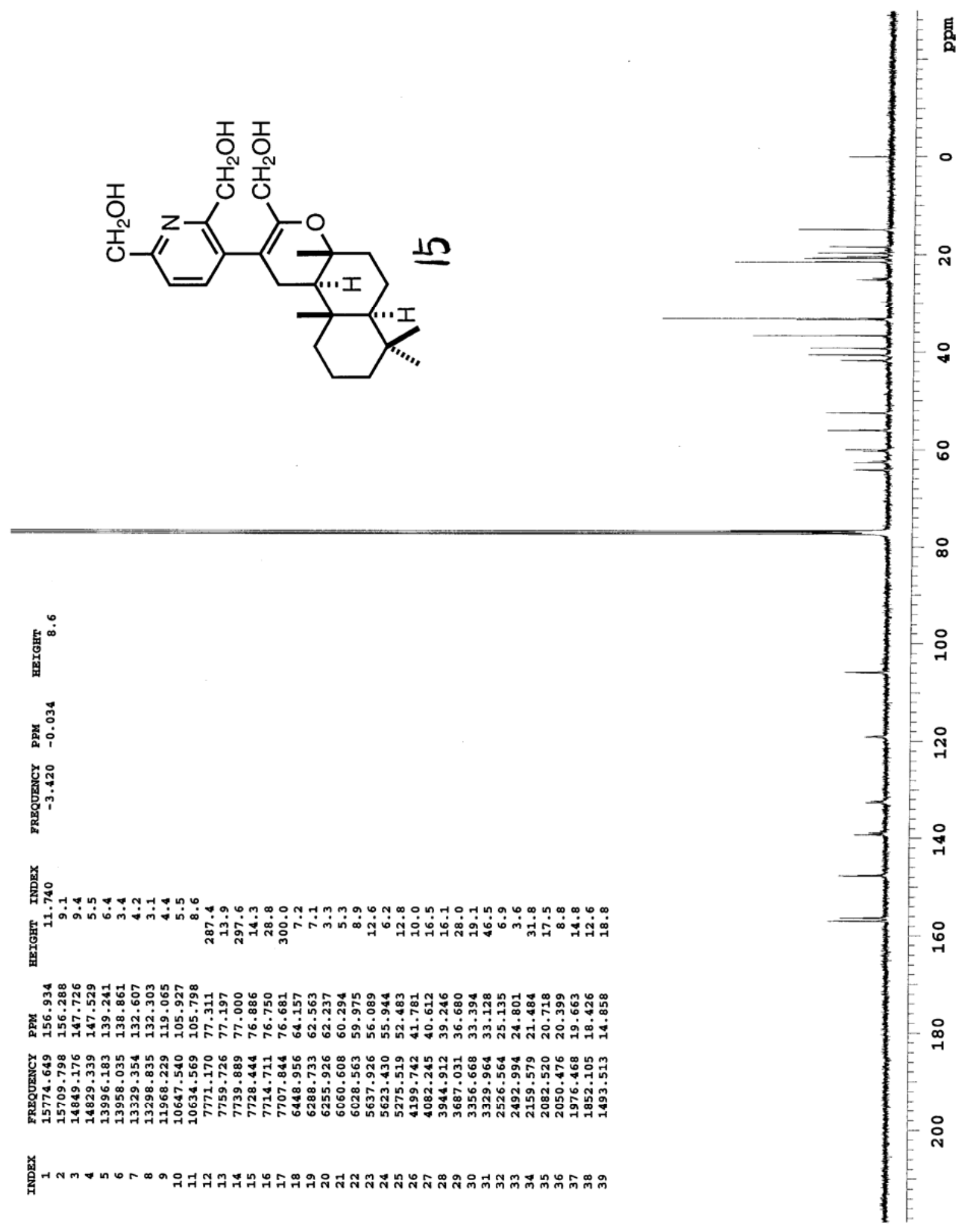




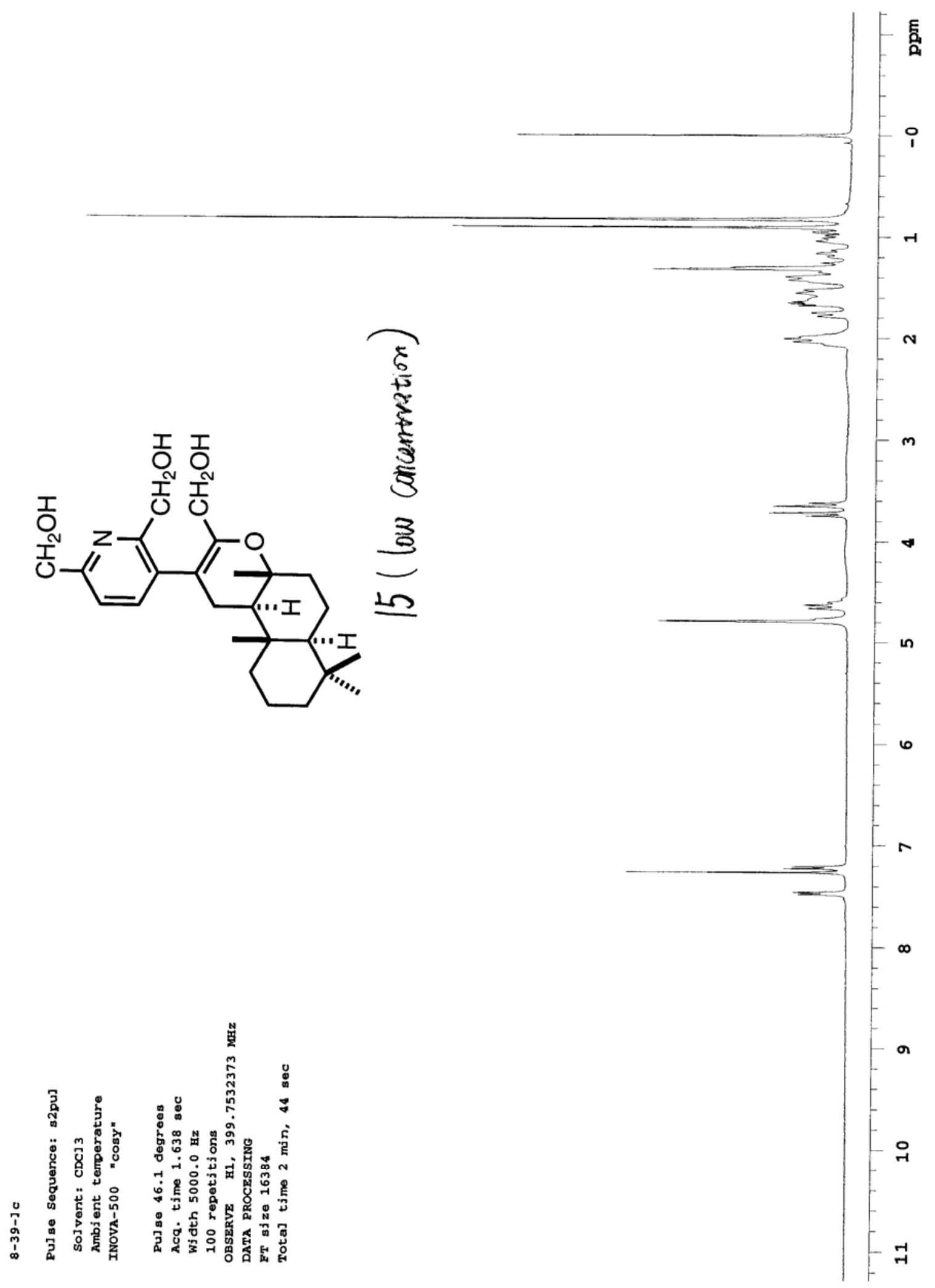




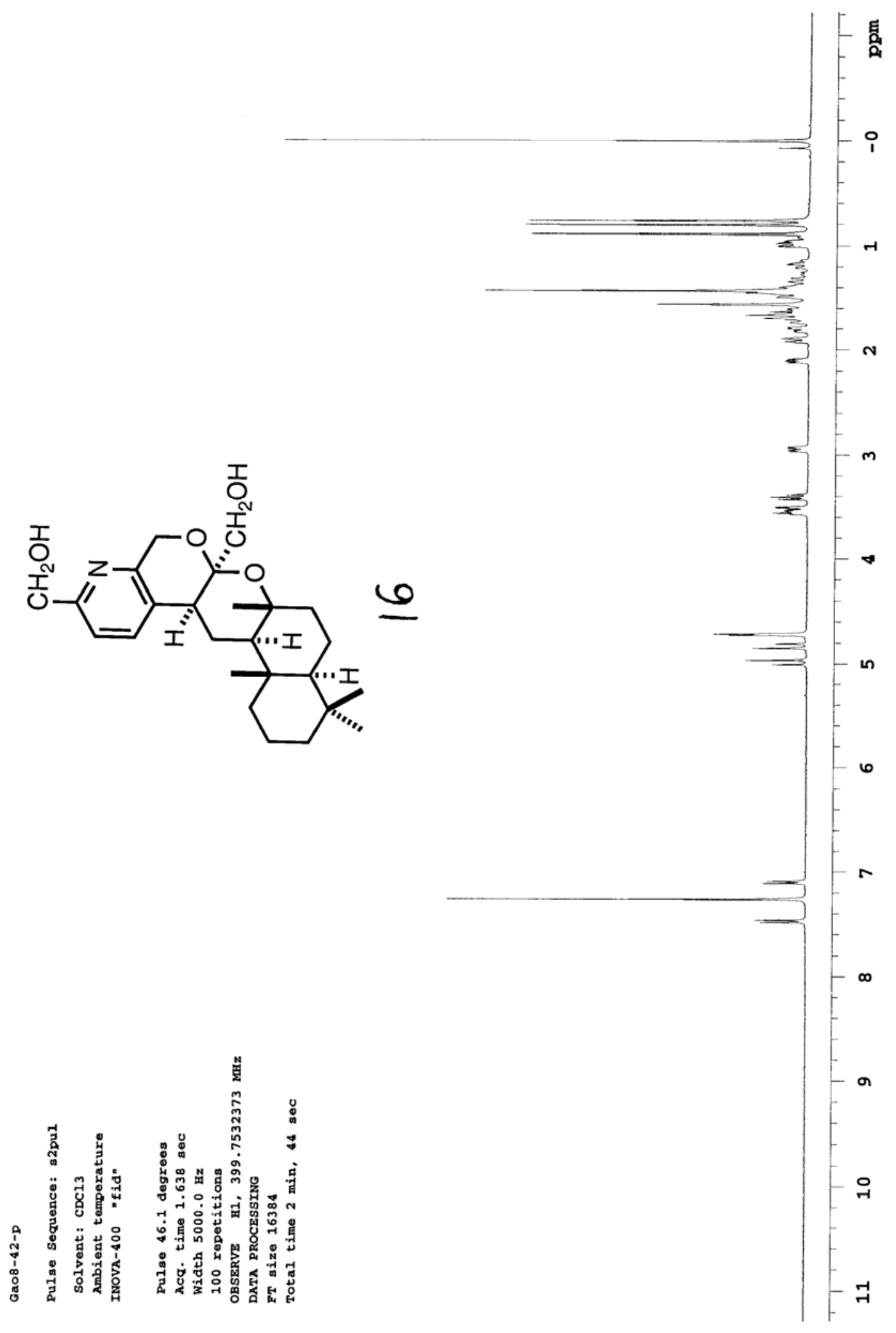




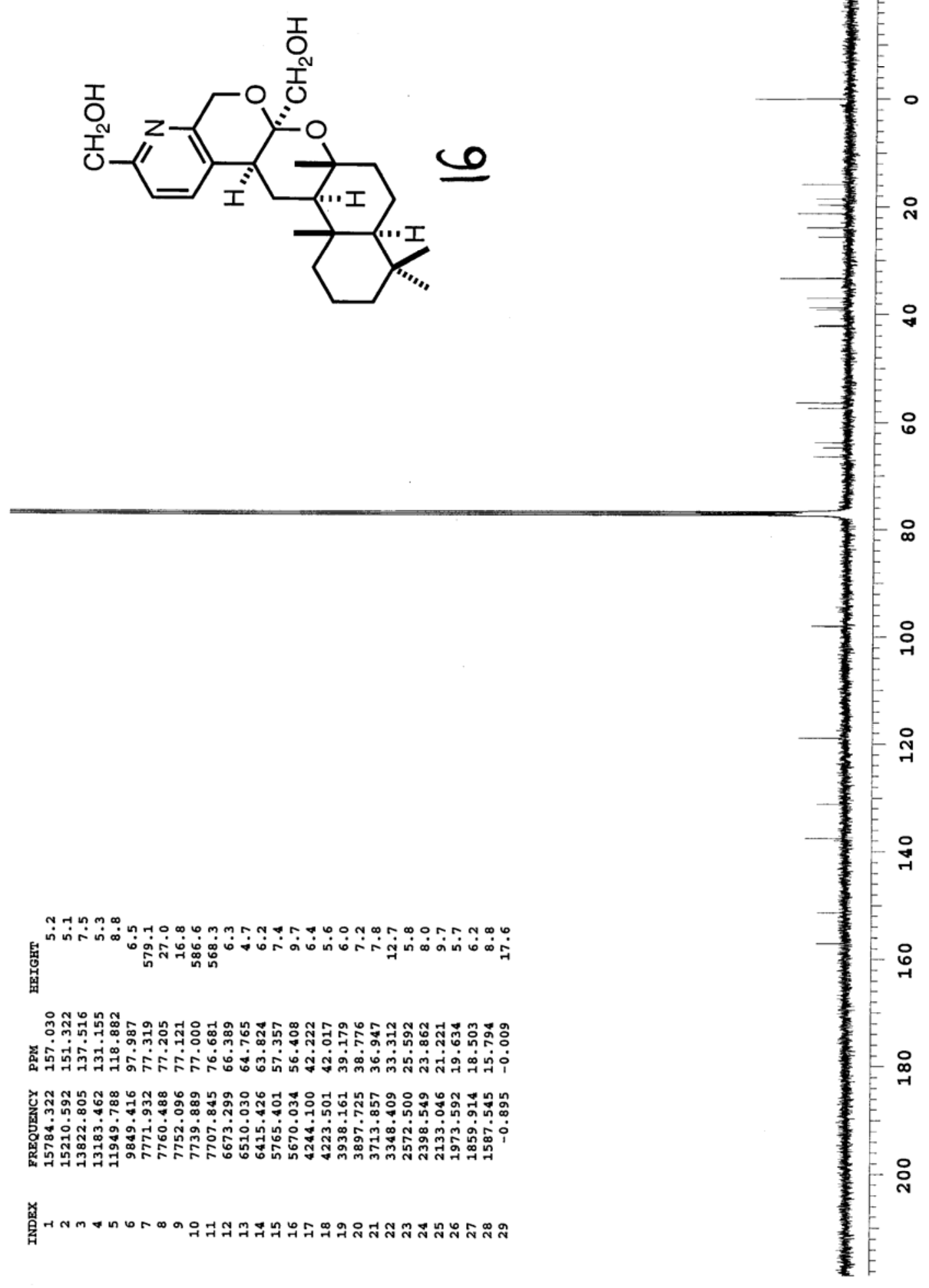

